\title{
A Study of Subsurface Drainage and Water Quality in Jeddah-Makkah Aquifer Zone, West Central Arabian Shield, Saudi Arabia
}

\author{
Mohammed Amin M. Sharaf \\ Faculty of Earth Sciences, King Abdulaziz University, Jeddah, \\ Saudi Arabia
}

\section{Introduction}

\subsection{Ground water in Saudi Arabia}

In arid regions where average annual rainfall is less than $200 \mathrm{~mm}$, recharge to local and regional aquifers is mostly indirect, very limited and insignificant (Lloyd 1999). Apart from the limited groundwater in shallow alluvial aquifers, most of the stored groundwater in local and regional sedimentary aquifers is non-renewable fossil water with varying ages between about 10,000-32,000 years.. The extensive use of groundwater, including the nonrenewable part, has been heavily practiced in several countries such as USA, Australia, Spain, India, Jordan, Oman, Libya, Bahrain, UAE, Egypt and Saudi Arabia, to support, agricultural and domestic activities. Saudi Arabia's intensive use of groundwater, including non-renewable fossil water, especially after the increase in its oil revenues in 1974, is an example for intensive utilization of groundwater for irrigated agriculture to support socioeconomic developments of natural communities.

Groundwater in Saudi Arabia is found almost entirely in the many thick, highly permeable aquifers of large sedimentary basins to the north, east, and groundwater occurs in the fractured, Precambrian crystalline rocks of the Arabian Shield, which is more significant in providing extensive, higher, relatively impermeable areas for surface runoff, and localised, shallow wadi underflow (Burden, 1982). While the major aquifers in the north of the country consist of multiple, Early Palaeozoic clastic permeable formations with interdigitated impermeable argillaceous strata, those in the eastern part include both karstified Tertiary carbonates and Mesozoic to basal Palaeozoic clastic formations. To the south of the Arabian Shelf, a single thick basal Early Palaeozoic sandstone formation constitutes a high yield aquifer. Groundwater is stored in more than 20- layered principal and secondary aquifers of different geological ages (Fig. 1) (MAW 1984).

The Arabian Shelf includes the deep sedimentary aquifers, which are formed mostly of limestone and sandstone that overlay the basement rocks and covers about two thirds of Saudi Arabia or 1,485,000 km2 (MAW 1984). The total thickness varies between a few hundred to more than 5,000 m (MAW 1984). The principal aquifers are: Saq, Wajid, Tabuk, Minjur, Dhruma, Biyadh, Wasia, Dammam, Umm Er Radhuma and Neogene. The secondary aquifers are: Al-Jauf, Al-Khuf, Al-Jilh, the Upper Jurassic, Sakaka, the Lower 
Cretaceous, Aruma, Basalts and Wadi Sediments (Fig. 1). The groundwater quality varies between sites and among aquifers. The isotopic analyses showed that the fossil groundwater in the above aquifers is 10,000-32,000 years old. Large volumes of groundwater are stored in the sedimentary aquifers (KFUPM/RI 1988). The estimated groundwater reserves to a depth of 300 meters below ground surface is about 2,185 km3, with a total annual recharge of 2,762 Mm3 based on several hydrogeological studies as given in KFUPM/RI (1988) and Alawi \& bdulrazzak (1994).

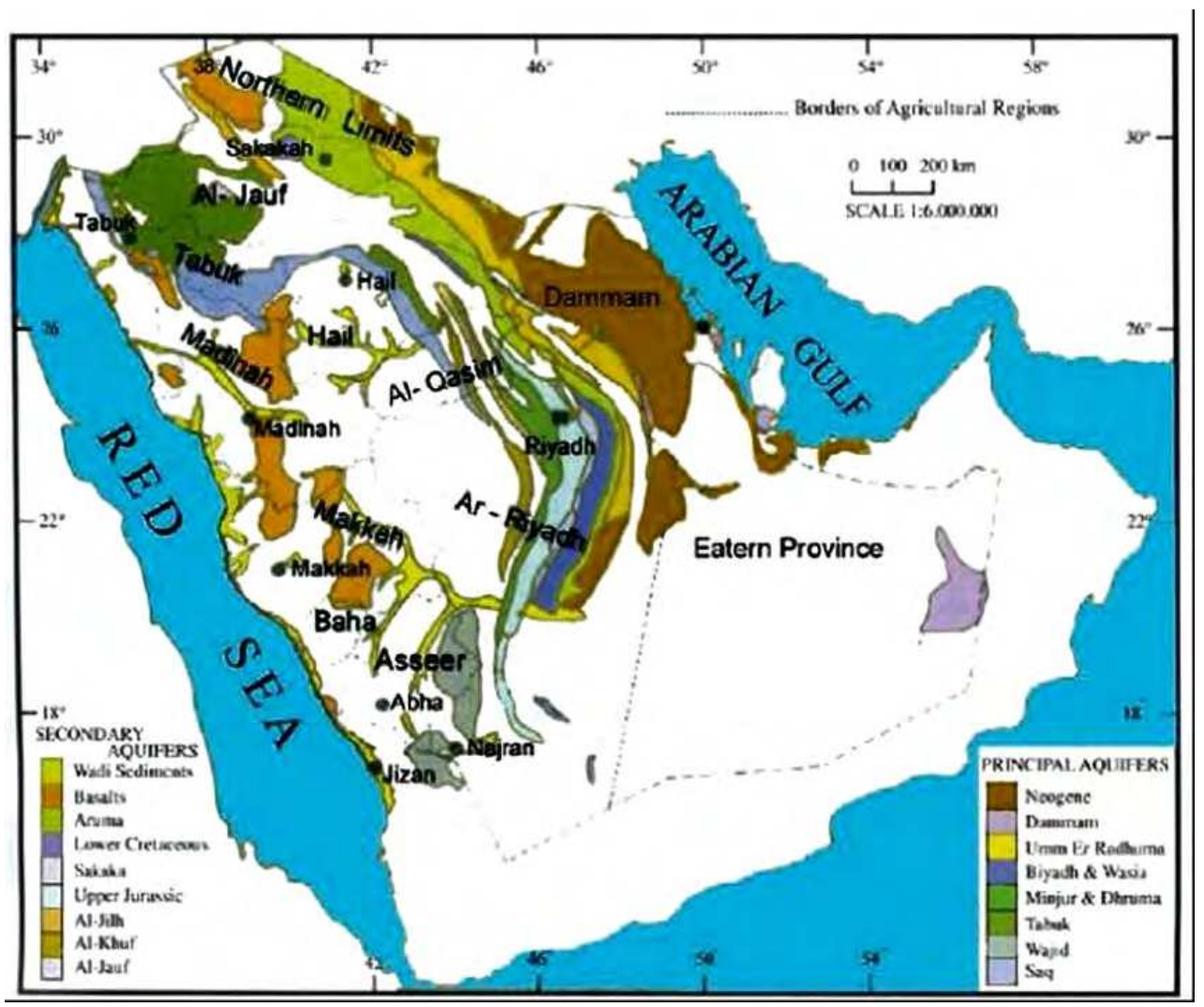

Fig. 1. The extension of the outcrop area of principle and secondary aquifers in agriculture regions in Saudi Arabia.

In arid regions, the irregularity of recharge leads to significant variations in quality of the groundwater from place to place and from time to time. The groundwater quality depends widely on such factors as the chemical composition of the water-bearing formation as well as residence with the aquifer.

For the planning of water resources management it is necessary to define water quality from the areal distribution and the genetic aspects, in order to establish as far as possible the qualitative effects of natural and human influence factors on the water quality. Hence, any fall off in groundwater quality may result in a big reduction in the percentage of resources 
that can be utilized or may create serious problems for domestic, agriculture and other activities. Therefore, there is a growing need to study the groundwater chemistry that include evaluation of major ions and trace elements concentrations and their effects on its suitability for different purposes.

\subsection{Water supply sources in Saudi Arabia}

The dependence on non-renewable groundwater resources has increased with time due to higher dependence of domestic and industrial water use on renewable groundwater in addition to desalination processes. The domestic and industrial water use depends mainly on desalination plants and renewable groundwater, while non-renewable groundwater water has been a secondary supplier to meet these demands. This study dealt with the hydrogeology and hydrochemistry of the groundwater aquifers in Jeddah- Makkah Al Mukarramah District, West Central Saudi Arabia. The study is based mainly on field observations and measurements augmented by may laboratory techniques.

\subsection{General climates and geology of the study area}

The study area lies within the western province of Saudi Arabia between latitudes 20॰54 00\ and 21。 $5723 \backslash \mathrm{N}$ and longitudes 39o $1709 \backslash$ and 40。 $0057 \backslash \mathrm{E}$ (Fig. 2). The present study will involve the three major drainage basins and their main tributaries. These are as follow: 1) Usfan, including, Haddat Ash Sham, Al Baydah-Mudsus, Ash Shamiyah and As Suqah sub-basins, 2) An Numan, including, Dayqah, Rahjan, Arar, Yarij and Uranah sub- basins, and 3) Fatimah, including, Al Sail Al Kabir, Al Yammaniyyah, Al Shamiyyah, Hawarah, Alaf, Bani Omair-Al Rayan and Al Jumum-Bahrah. All the basins lying partially within the Arabian Shield, while their lower parts are on the Red Sea coastal plain.

Several hydrogeological research activities were carried out in the study area since the early seventies. Most of these works were concerned with the groundwater condition, aquifer characteristics and the groundwater quality in the wadi sediments (e.g. Italconsult, 1976; AlKhatib, 1977; Al-Hajeri, 1977; Jamman, 1978; Al-Nujaidi, 1978; Al-Gamal and Sen, 1983; Mansour, 1984; Sharaf et al. 1988; Al Kabir, 1985; Basmci and Al-Kabir, 1988; Alyamani and Hussein, 1995; Alyamani et al. 1996; and Alyamani, 1999). A few studies concerned with the trace elements concentrations such as $\mathrm{Mn}, \mathrm{Pb}, \mathrm{Si}, \mathrm{Al}, \mathrm{F}$ and $\mathrm{B}$ in the groundwater are available .i.e. Bazuhair et al. (1992) outlined comprehensive investigations on groundwater condition included water chemistry within Khulais basin. Detailed hydrogeological and hydrochemical studies were carried out in Wadi Usfan by Sharaf et al. (2002). Several detailed studies regarding geological and geomorphological characteristics of the area around An Numan basin are available (e.g. Brown et al. 1963; Zaidi, 1983 and 1984; Moore and Al-Rehaili, 1989).

The climatic conditions all over the study area may play an important role in defining the hydraulic response of the watersheds and groundwater quality existing in the region. Generally, the climate is typically arid and the rainfall is irregular and has torrential nature. The rainfall occurs during winter season, while in the autumn and spring the area is subjected to isolated events. The average annual rainfall is about $60 \mathrm{~mm}$ in the lowland areas. Where, moving towards the eastern direction the rainfall increases to more than 170 $\mathrm{mm} /$ year. Such variation in the rainfall amount can be attributed to the orographic effects of 
the Red Sea escarpment. Rainfall distribution over the study area was characterized in time and space. Data from the five rainfall gauges were used to establish the rainfall distribution. The variation of rainfall in the spatial dimension reflects the topographic effects, since the highest values were recorded at the highest stations. The average monthly rainfall was computed in order to give an approximate idea of the seasonal variation in the local rainfall patterns. All effective rainfall is concentrated between November and April (with very minor exceptions in early May).

From the geologic points of views, the study area comprises Precambrian-Cambrian basement complex, Cretaceous-Tertiary sedimentary succession, the Tertiary- Quaternary basaltic lava flows, and the Quaternary-Recent alluvial deposits (Fig. 3). The Precambrian rock units in the study area consist of Late-Proterozoic basaltic to rhyolitic volcanic and volcanoclastic and epiclastics of primitive island-arc type, that have been multiply deformed and metamorphosed and injected by intrusive bodies of different ages and compositions. These rock units are divided into Zibarah, Samran, and Fatimahh groups (sedimentary rocks). Plutonic rock units are gabbro, diorite, tonalite and granodiorite to monzonite of probably early Cambrian ages.

The Cretaceous-Tertiary sedimentary succession is exposed beneath a cover of flat-lying lavas and Quaternary deposits in the study area. This succession is subdivided into the Haddat Ash Sham, Shumaysi, Khulays, and Buraykah formations. It consists of clastic rocks dominated by sandstones, shale, mudstones, oolitic ironstones, and occasionally conglomerates. A middle Cretaceous age has been assigned to Haddat As Sham Formation. Basalt lava flows form discontinuous caps overlying

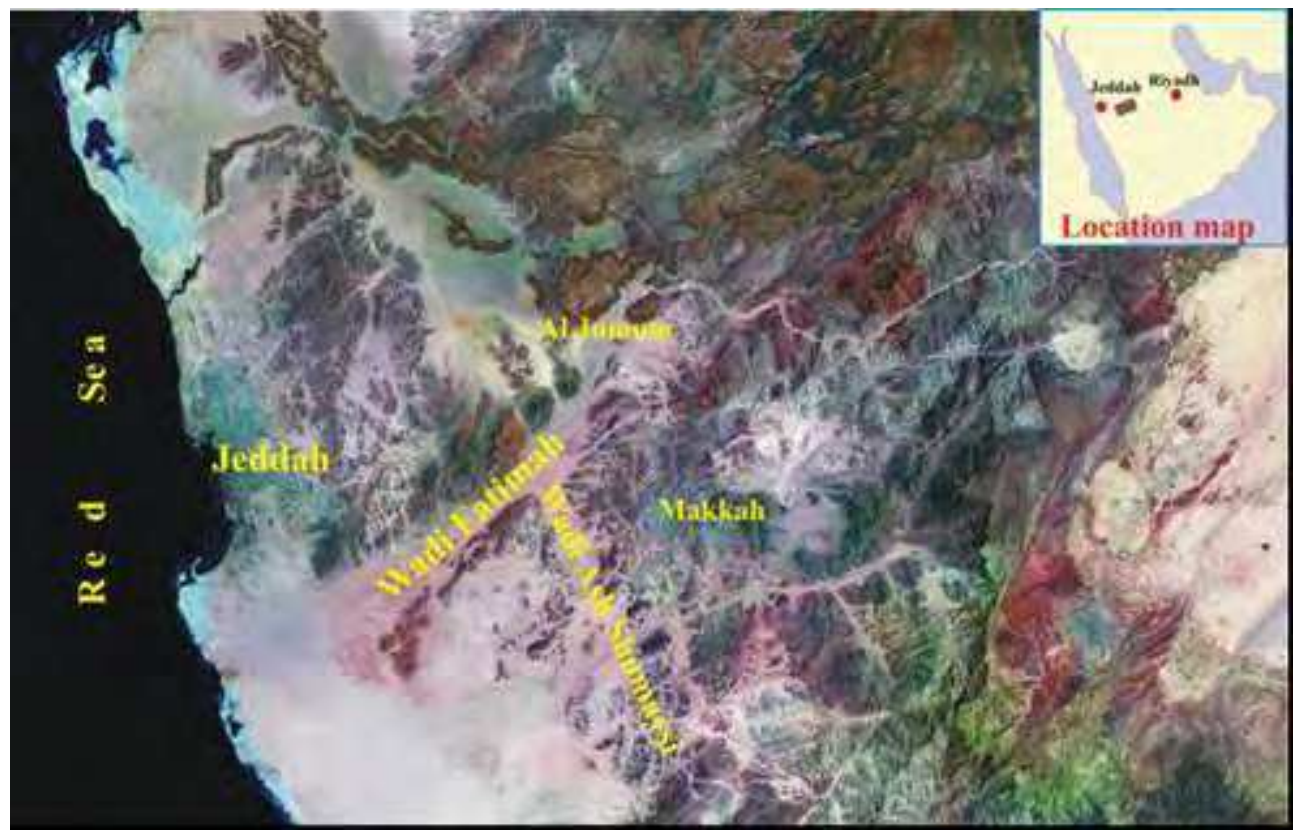

Fig. 2. Satellite image of the study area. 
the upper levels of both the basement complex and the sedimentary rocks; the lavas are either rest on peneplain or infilled ancient wadis. They are preserved in three northnorthwest trending, asymmetric depositional troughs which are the Sham, Suqah and Shumaysi troughs. These troughs are bounded in the north by faults downthrown to the west and in the west by an unconformity at the base of the easterly dipping strata.

Quaternary deposits cover large parts of the study area. They principally occur in the large drainage basins of Haddat Ash Sham. The principle units of the Quaternary rocks are the terrace gravel, alluvial fan deposits, tallus deposits, alluvial sands and gravels of wadi beds and some eolian edifices. The thickness of these deposits varies widely from one place to another.

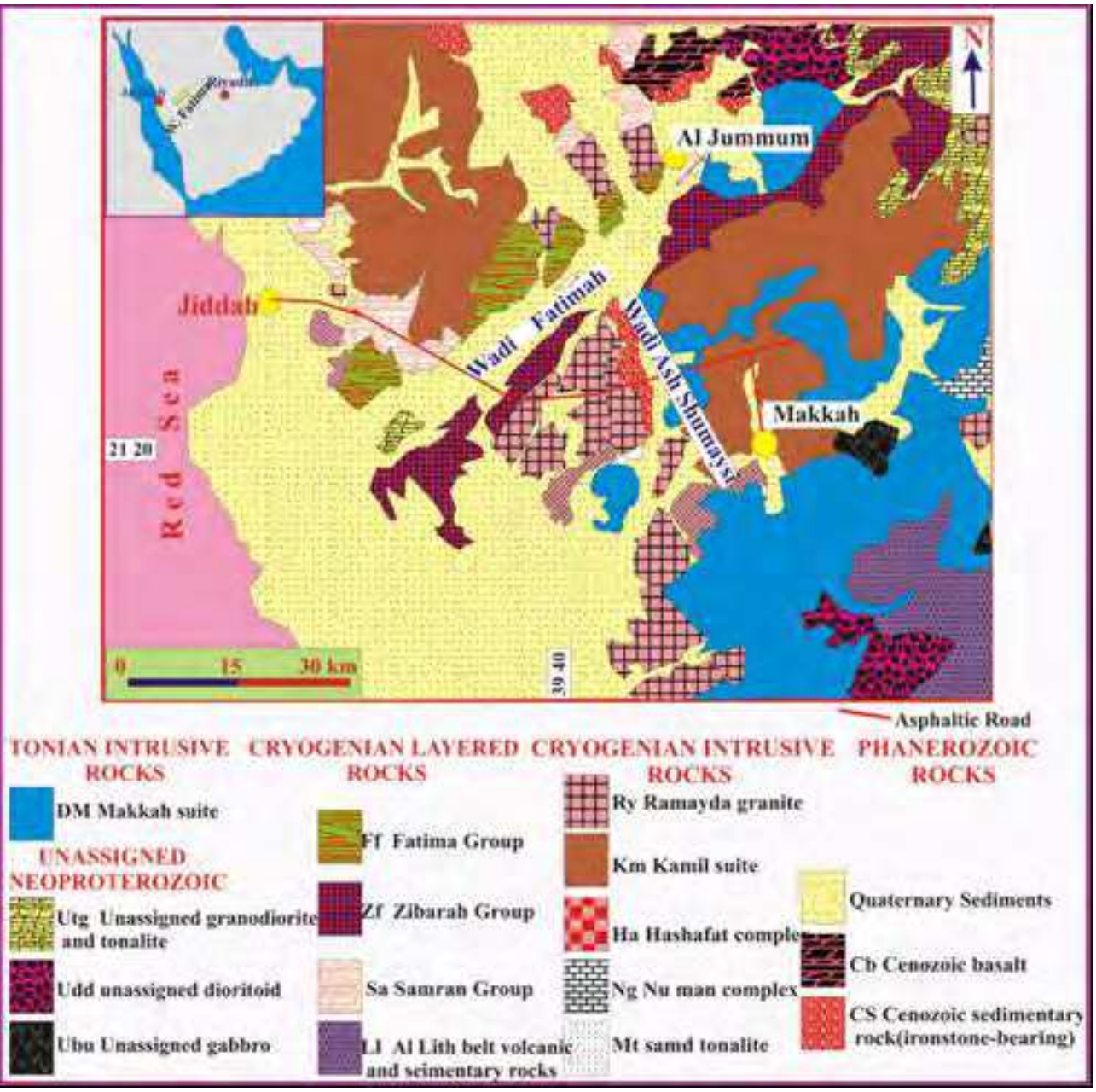

Fig. 3. Geologic map of Makkah district including Wadi Usfan, Wadi Fatimah and wadi An Numan (Petter Johnson, 2006). 


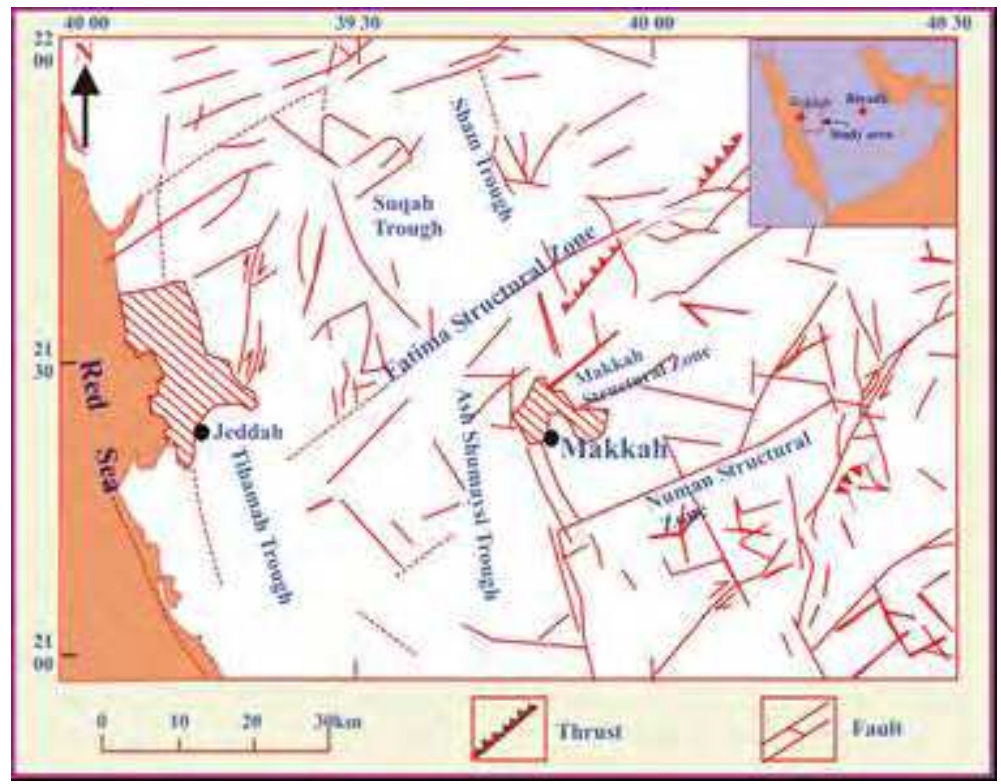

Fig. 4. General structural geologic map of Makkah district including W. As Suqah area (after Sharaf, 2011b).

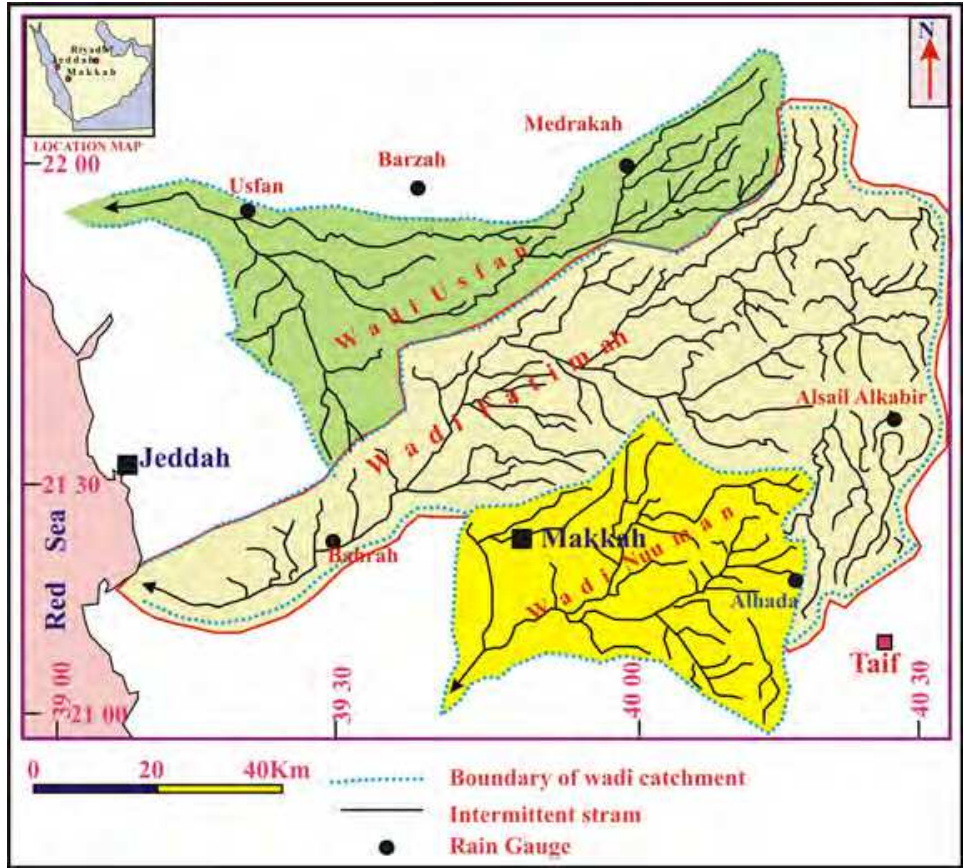

Fig. 5. Drainage basin map of the studied basins (Sharaf, 2011a). 
Three main sets of faults: NW, NE and N (Fig. 4). The NW faults are the oldest and seem to have controlled the depositional troughs in the study area, mainly those of Haddat Ash Sham and As Suqah. They are mostly normal faults dipping steeply to the southwest. The NE faults displace the NW set and seem to be second component in block faulting. The $\mathrm{N}$ trending faults are shear faults with lateral displacement for the above mentioned NW and NE sets.

Three distinctive geomorphologic zones in the study area are present, namely the mountainous region in the extreme east, the pediment region and the coastal plain (Fig. 5). The mountainous region comprises mostly folded and faulted Precambrian rocks (Hijaz Highlands) and Tertiary lave flows (Harrat Rahat). They form a longitudinal block that extends from the north to the south. The pediments bound the mountainous region from the west and are marked by their elongated features, which trend in a westerly direction and sometimes appear as small knobs.

The pediments are marked by thin layer of alluvial and aeolian sediments resting on highly weathered surface of Precambrian rocks. The mountainous region is mainly a recharge area, while the pediment region may be considered as an area of surface flow.

\subsection{Data of recharge area}

The rainfall data collected from five rain gauges stations; these are Alhada, Alsail Alkabir, Bahrah, Barzah, and Medrakah. The collected data are in the form of daily rainfall for different number of years. These data were collected from the Hydrology section of the Ministry of Agriculture and Water (MAW) and from Meteorology and Environmental Protection Administration (MEPA). A total of 400 groundwater samples were collected from the privately owned drilled wells within the studied basins. Most of the groundwater samples were taken from intensively pumped wells in order to avoid any local contamination or change in chemistry caused by evaporation or gas exchange in the well

\begin{tabular}{|c|c|c|c|c|c|c|c|c|c|c|c|c|c|}
\hline $\begin{array}{c}\text { STATION } \\
\text { NAME }\end{array}$ & Jan & Feb & Mar & Apr & May & Jun & Jul & Aug & Sep & Oct & Nov & Dec & $\begin{array}{c}\text { Elevation } \\
\text { m.a.s.l }\end{array}$ \\
\hline $\begin{array}{c}\text { Alhada } \\
(1980-1992)\end{array}$ & 22.4 & 7.0 & 18.3 & 19.6 & 30.4 & 2.5 & 0 & 8.0 & 7.6 & 14.4 & 21.2 & 36.7 & 1940 \\
\hline $\begin{array}{c}\text { AlsailAlkabir } \\
(1982-1993)\end{array}$ & 5.3 & 0.4 & 5.7 & 17.7 & 12.0 & 1.6 & 0.2 & 0.9 & 2.6 & 1.7 & 7.6 & 10.8 & 1230 \\
\hline $\begin{array}{c}\text { Bahrah } \\
(1966-1997)\end{array}$ & 18.0 & 4.0 & 1.5 & 4.2 & 1.2 & 0 & 0 & 2.0 & 1.5 & 0.9 & 11.4 & 18.0 & 116 \\
\hline $\begin{array}{c}\text { Barzah } \\
(1976-1997)\end{array}$ & 8.5 & 3.9 & 7.0 & 7.0 & 0.8 & 1.9 & 0.7 & 2.7 & 5.5 & 1.1 & 18.0 & 15.0 & 350 \\
\hline $\begin{array}{c}\text { Medrakah } \\
(1966-1996)\end{array}$ & 16.6 & 3.9 & 7.7 & 23.2 & 9.0 & 1.1 & 4.0 & 3.5 & 13.6 & 7.9 & 12.9 & 7.1 & 710 \\
\hline
\end{tabular}

Table 1. Average monthly rainfall for different rain gauges (mm) (Sharaf, 2011a). 
itself rainfall distribution over the study area was characterized in time and space. Data from the five rainfall gauges (Fig. 5 \& Tab. 1) were used to establish the rainfall distribution. This table shows that the variation of rainfall in the spatial dimension reflects the topographic effects, since the highest values were recorded at the highest stations (Medrakah, Alsail Alkabir, and Alhada, Fig. 5). The average monthly rainfall was computed in order to give an approximate idea of the seasonal variation in the local rainfall patterns. All effective rainfall is concentrated between November and April (with very minor exceptions in early May).

\section{Wadi Usfan}

From the geologic point of view, the study area comprises Precambrian-Cambrian basement rocks, Cretaceous-Tertiary sedimentary succession, the Tertiary- Quaternary basaltic lava flows, and the Quaternary-Recent alluvial deposits. Wadi As Suqah is a NW-SE low lands surrounded from the west by Precambrian rocks overlain by black basaltic lava flows (Harrat, Fig. 6, 7).

Precambrian rocks of wadi Usfan have been classified by Moore and Al-Reheili (1989) into Late- Proterozoic basaltic to rhyolitic volcanic and volcanoclastic and epiclastics of primitive island-arc type, that have been deformed and metamorphosed during many times and injected by intrusive bodies of different ages and compositions.

Sedimentary rock units of Usfan basin have been classified by Petter Johnson (2006) into: 1The Cryogenian layered rocks which are represented by the Samran Group (sa), 2- The Cryogenian intrusive rocks which are represented by The Hishash granite (ig) which intrudes the Kamil Suite and Samran Group and composed of monzogranite and subordinate granodiorite (Moore and Al-Rehaili, 1989) and the Kamil Suite (km) which consists of mafic, intermediate, and felsic plutonic rocks of calc-alkalic and locally trondhjemitic affinities and, 3- The Edicarian layered rocks are represented by Shayma Nasir Group (Sn), which includes polymict conglomerate; basaltic, andesitic, dacitic, and rhyolitic lava, tuff, and agglomerate; and red-brown arkosic, volcaniclastic, and calcareous sandstone.

Cenozoic rock units of Usfan Basin (CS) are exposed beneath a cover of flat-lying lavas and Quaternary deposits. Brown and others (1963) introduced the names Shumaysi and Usfan formations to these sedimentary sequences after Karpoff (1958). Spincer and Vincent (1984) divided the Shumaysi Formation into the Haddat Ash Sham, Shumaysi, Khulays, and Buraykah formations.

Sharaf (2009 a and b) carried out a geophysical and hydrochemical study on Haddat Ash Sham and Ash Shamiyah areas and concluded that, the groundwater is mainly present in the Quaternary alluvial deposits and the Tertiary sandstones and conglomerates of Haddat Ash Sham and Ash Shumaysi Formations. In As Suqah area (Fig. 6), the groundwater is present within two main water-bearing units: the alluvium of the Wadi system under unconfined conditions and within the clastic layers of the Cretaceous sedimentary succession. The general groundwater flow in the aquifer system follows the surface drainage towards the northwest to Usfan city; it takes place from areas of high potential to areas of low potential (Fig. 8). Both the elevation and pressure heads define the direction of groundwater flow towards northwest. The values of the depth to water in Table 1 represent 
the absolute depth to the water while the values of the contour lines showing the flow direction in Fig. 7 represents the water depth above sea level (a. s. 1.).

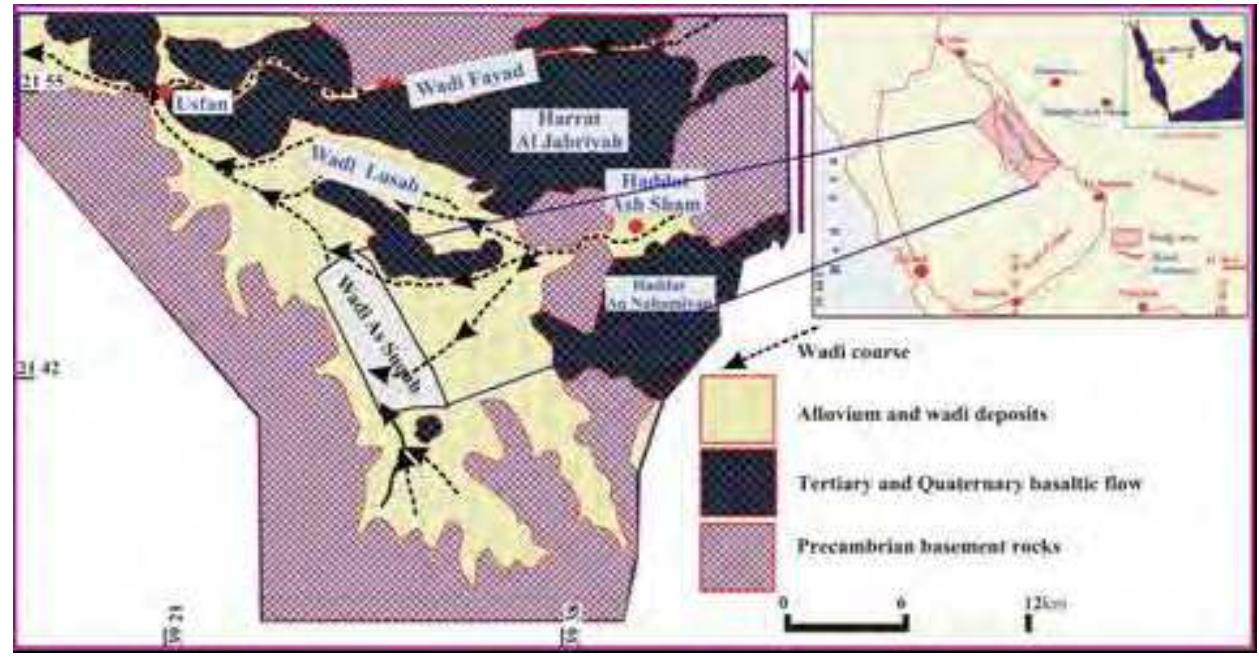

Fig. 6. Simplified geologic map of Usfan basin (Sharaf, 2011b).

In Usfan basin, the geological and geophysical exploration for groundwater is based mainly on integrated electro-resistivity (VES, Fig. 9), and four drilled test wells (Fig. 10) and seismic and magnetic geophysical tools. The results of theses exploration tools revealed the following conclusions: 1) Groundwater occurs mainly in two water-bearing horizons, the alluvial deposits and within the clastic sedimentary rocks of Haddat Ash Sham and Ash Shumaysi formations. The shallow zone is characterized with a saturated thickness of 3- 20 $\mathrm{m}$ and water is found under confined to semi-confined conditions, 2) Water levels were encountered at depths varying from $3-16 \mathrm{~m}$ in the alluvial wadi deposits, and from 18-62 $\mathrm{m}$ in the sedimentary succession, 3) Groundwater movement is towards the west and northwest, following the general surface drainage system, and 4) Hydraulic gradient varies greatly from one point to another depending on the pumping rates and cross-sectional area of the aquifer in addition to its transmissivity.

The locations of the water wells of wadi Usfan (Fig. 7A) show the localization of these wells in the southeastern (upstream) part of the wadi. The cation composition varies between almost exclusively $\mathrm{Na}+$ to dominantly $\mathrm{Ca}^{2+}$ and $\mathrm{Mg}^{2+}$ with relatively lesser amount of $\mathrm{K}^{+}$. Among the anions, $\mathrm{Cl}^{-}$is dominant. They also reflect that $\mathrm{HCO}^{3-}$ and $\mathrm{K}^{+}$ions seem to be rather uniform distribution. The ionic concentration of the groundwater samples has the following general pattern:

$$
\mathrm{Na}^{+}>\mathrm{Ca}^{2+}>\mathrm{Mg}^{2+}>\mathrm{K}^{+} \text {and } \mathrm{Cl}^{-}>\mathrm{SO}_{4}{ }^{2-}>\mathrm{HCO}_{3}^{-}
$$

On the other hand, the spatial distributions of the major ions shown that the major constituents followed the general trend of the groundwater salinity (EC) in the basin.

The chemical analyses of the trace elements shown that, each element has its own dispersion in the area without any general trend of distribution. Such pattern occurred reflecting that 
most of these elements are probably locally affected as a result of chemical reactions between groundwater and the parent rocks. However, the majority of these elements were marked in As Suqah and Ash Shamiyah regions, such as B, As, Al, Mn, Li, Cd, Ba, Cr, and Mo. The high concentrations of these elements is almost present adjacent to the basaltic lava in the middle part of the study area, reflecting that the chemical weathering of basalt may consider as a source of them. Haddat Ash Sham, on the other hand, characterized by high contents of $\mathrm{Hg}, \mathrm{Cu}, \mathrm{Co}, \mathrm{F}$ and $\mathrm{PO}_{4}$.

In Wadi Usfan, the water quality is highly variable. The groundwater salinity is nonuniform aerially, and there are wide differences among the individual wells as well as the sub-areas. Mean values and ranges of the EC measurements for each sub-area (i.e. Haddat Ash Sham, Ash Shamiyah, Al Baydah-Mudsus and As Suqah) are shown in Table 2. Both Haddat Ash Sham and Ash Shamiyah sub-basins are characterized by relatively low saline water, whereas, highly mineralized water almost marked Wadi As Suqah sub-basin where the groundwater salinity reached up to $30,000 \mu \mathrm{S} / \mathrm{cm}$ with an average of about $18800 \mu \mathrm{S} / \mathrm{cm}$. The EC measurements of the groundwater within Haddat Ash Sham and Ash Shamiyah sub-basins indicated that few wells yield relatively low saline water (< $1500 \mu \mathrm{S} / \mathrm{cm}$ ). These are distributed randomly and are often near wells providing moderately mineralized water. It also observed that within these two areas, the groundwater from wells drilled in the center of the wadi alluvium are not as mineralized as the waters extracted from wells located along the edges of the wadi channel. The EC and $\mathrm{SO}_{4}$ (Fig. $7 \mathrm{~B}, \mathrm{C}$ respectively) distribution shows that the groundwater salinity almost increased towards the downstream part of the wadi, which probably matches the general flow of the groundwater.

The dominant water types are $\mathrm{NaCl}$ and $\mathrm{CaCl}_{2}$. On the other hand, a few wells yield medium to high saline water. Those are concentrated in Wadi Haddat Ash Sham, Ash Shamiyah and Al Baydah-Mudsus sub-basins. These are fallen within the satisfactory limits and can be used safely for agricultural practices. In contrast, Wadi As Suqah sub-basin shown highly saline water, although they reflected low to high SAR values. Under this condition, the groundwater tends to restrict its utilization for agricultural activities. The concentration of $\mathrm{NO}_{3}$ - ions is relatively high. The major sources of $\mathrm{NO}_{3}$ - probably as a result of intensive use of chemical fertilizers in these regions. Poultries may also considered as another source of $\mathrm{NO}_{3}^{-}$particularly in the upper part of Wadi Ash Shamiyah in Usfan basin. The concentration of $\mathrm{NO}_{3}$ - ions is relatively high. The major sources of $\mathrm{NO}_{3}^{-}$probably as a result of intensive use of chemical fertilizers in these regions. Poultries may also considered as another source of $\mathrm{NO}_{3}^{-}$particularly in the upper part of Wadi Ash Shamiyah in Usfan basin.

\begin{tabular}{|c|c|c|c|c|}
\hline Basin Name & Sub-Basin Name & Maximum & Minimum & Mean \\
\hline \multirow{3}{*}{ WADI USFAN } & Haddat Ash Sham & 8600 & 875 & 3699 \\
\cline { 2 - 5 } & Ash Shamiyyah & 10890 & 1808 & 6482 \\
\cline { 2 - 5 } & Mudsus-Al Baydah & 11940 & 2200 & 5504 \\
\cline { 2 - 5 } & As Suqah & 30800 & 7720 & 18837 \\
\hline
\end{tabular}

Table 2. Average groundwater salinity in Usfan sub-basins. 


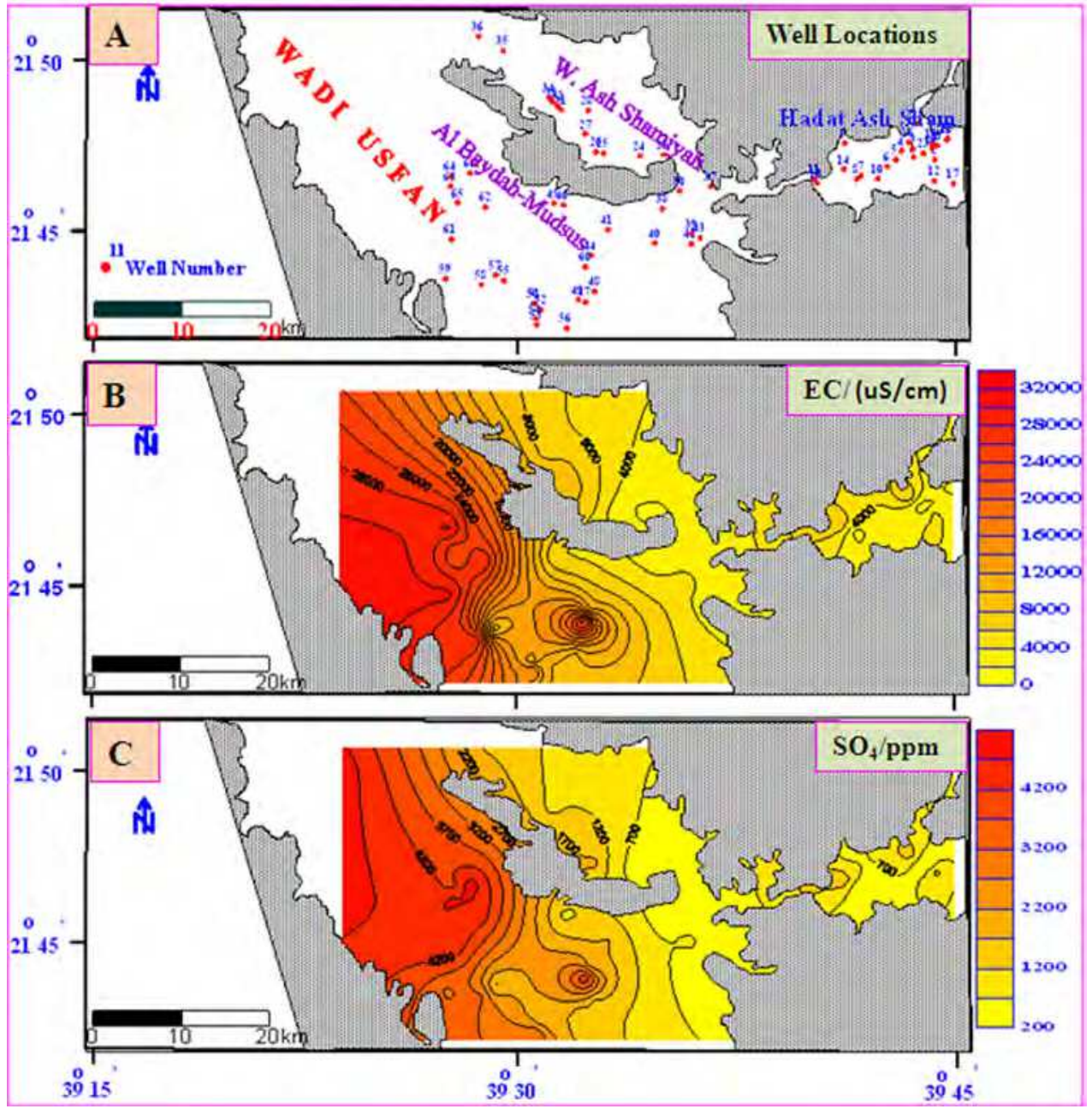

Fig. 7. $\mathrm{A}=$ Well locations in wadi Usfan; $\mathrm{B}=\mathrm{EC}$; and $\mathrm{C}=\mathrm{SO}_{4}$ content of the groundwater of wadi Usfan. 


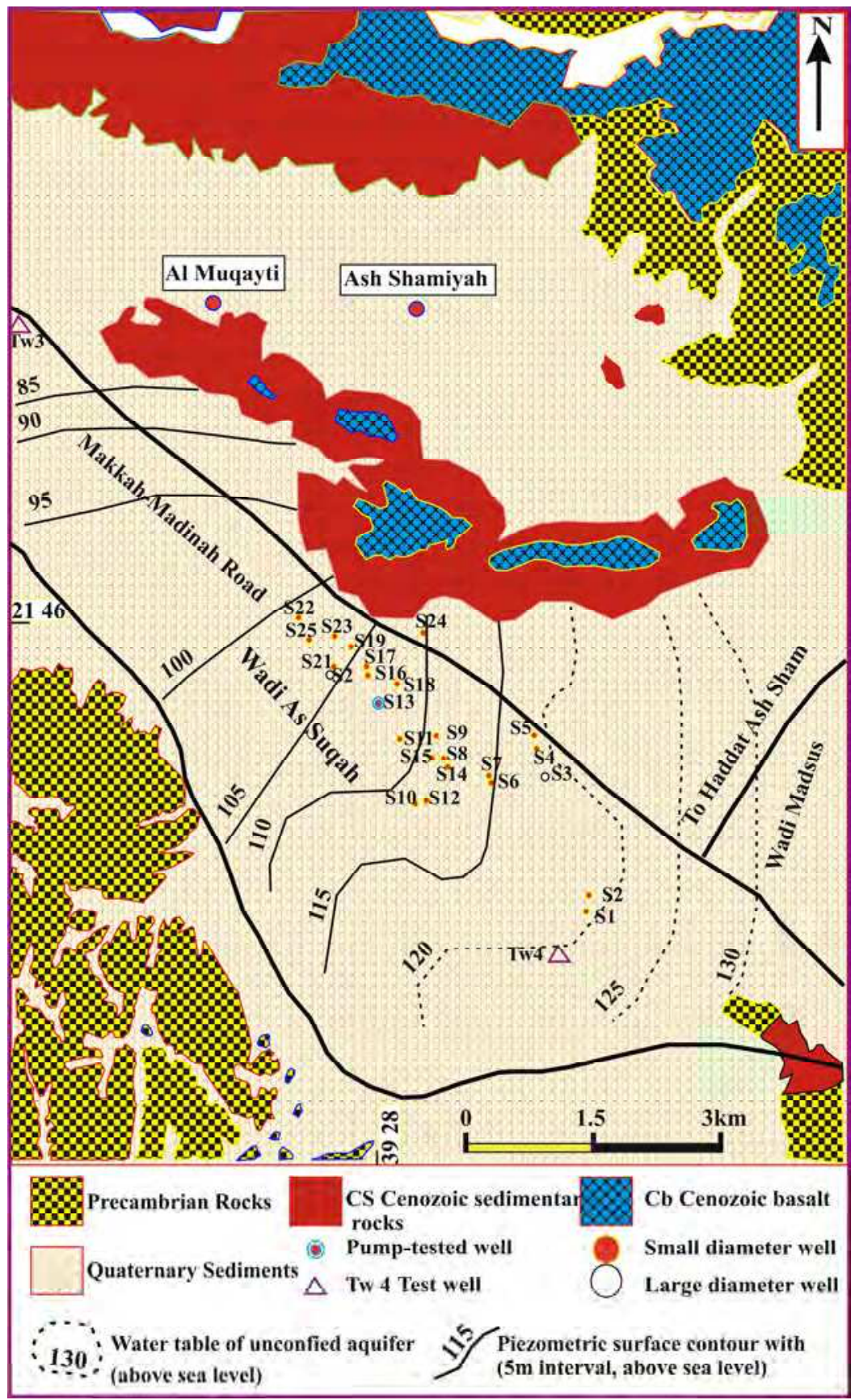

Fig. 8. Detailed geologic map showing the locations of the studied boreholes of As Suqah area (Sharaf, 2011d). 


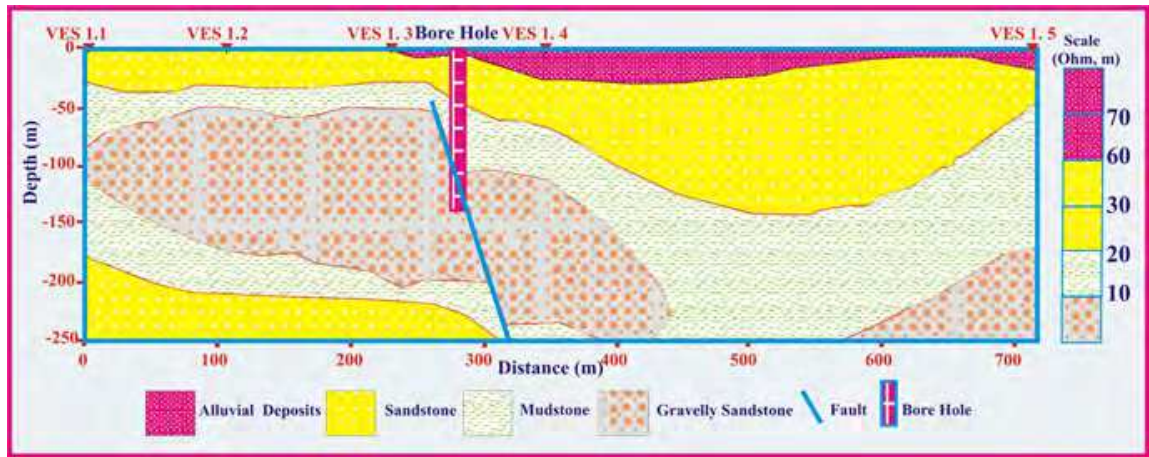

Fig. 9. Haddat Ash Sham (Usfan Basin) geo-electrical cross-section (Sharaf, 2011b).

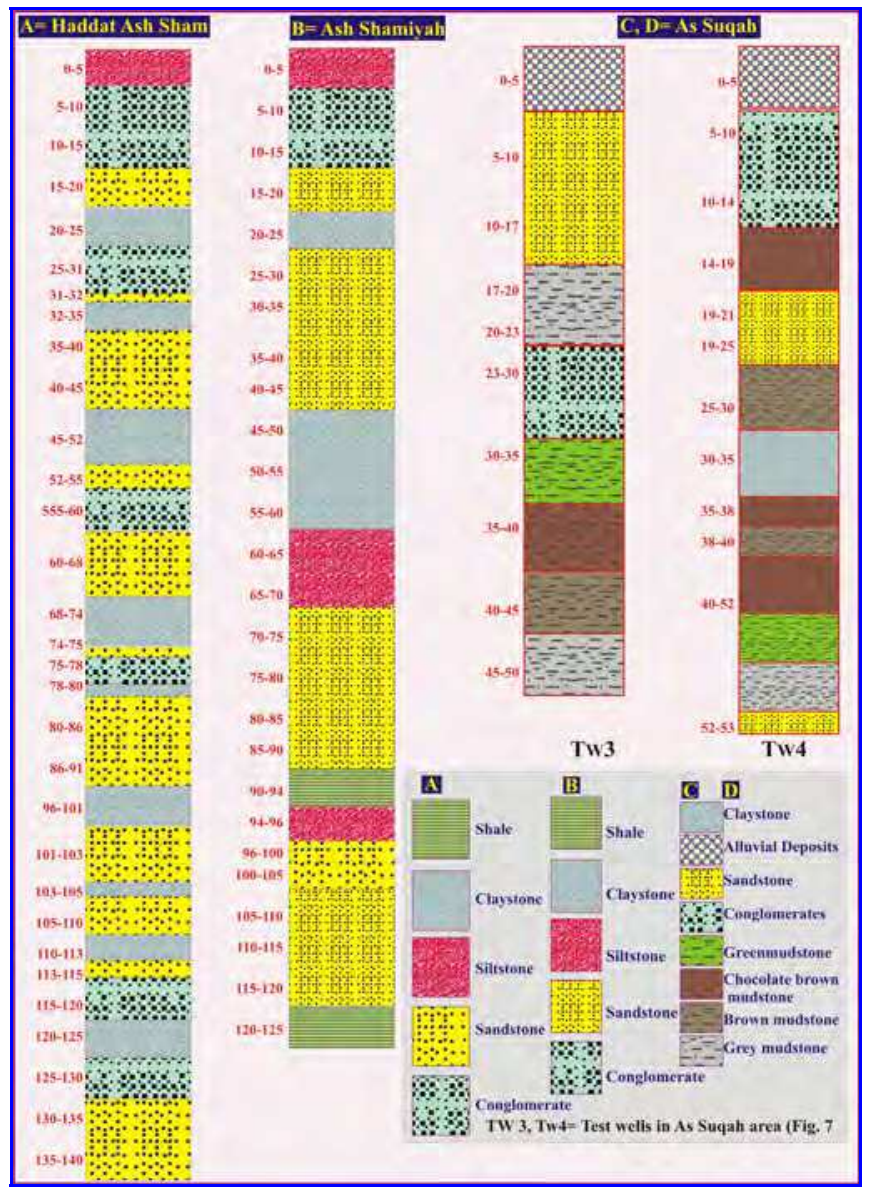

Fig. 10. Stratigraphic logs of the drilled test wells in Usfan basin (Modified from Sharaf, 2010a, b and 2011b). 


\section{Wadi An Numan}

An Numan basin mainly originate in the Hijaz Highlands (Fig. 11). The drainage of the basins is generally well developed and the pattern is typically dendritic (Fig. 5). Three distinctive geomorphologic zones in the study area are present, namely the mountainous region in the extreme east, the pediment region and the coastal plain. The mountainous region comprises mostly folded and faulted Precambrian rocks (Hijaz Highlands) and Tertiary lave flows (Harrat Rahat). They form a longitudinal block that extends from the north to the south. The pediments bound the mountainous region from the west and are marked by their elongated features, which trend in a westerly direction and sometimes appear as small knobs. The pediments are marked by thin layer of alluvial and aeolian sediments resting on highly weathered surface of Precambrian rocks. The mountainous region is mainly a recharge area, while the pediment region may be considered as an area of surface flow.

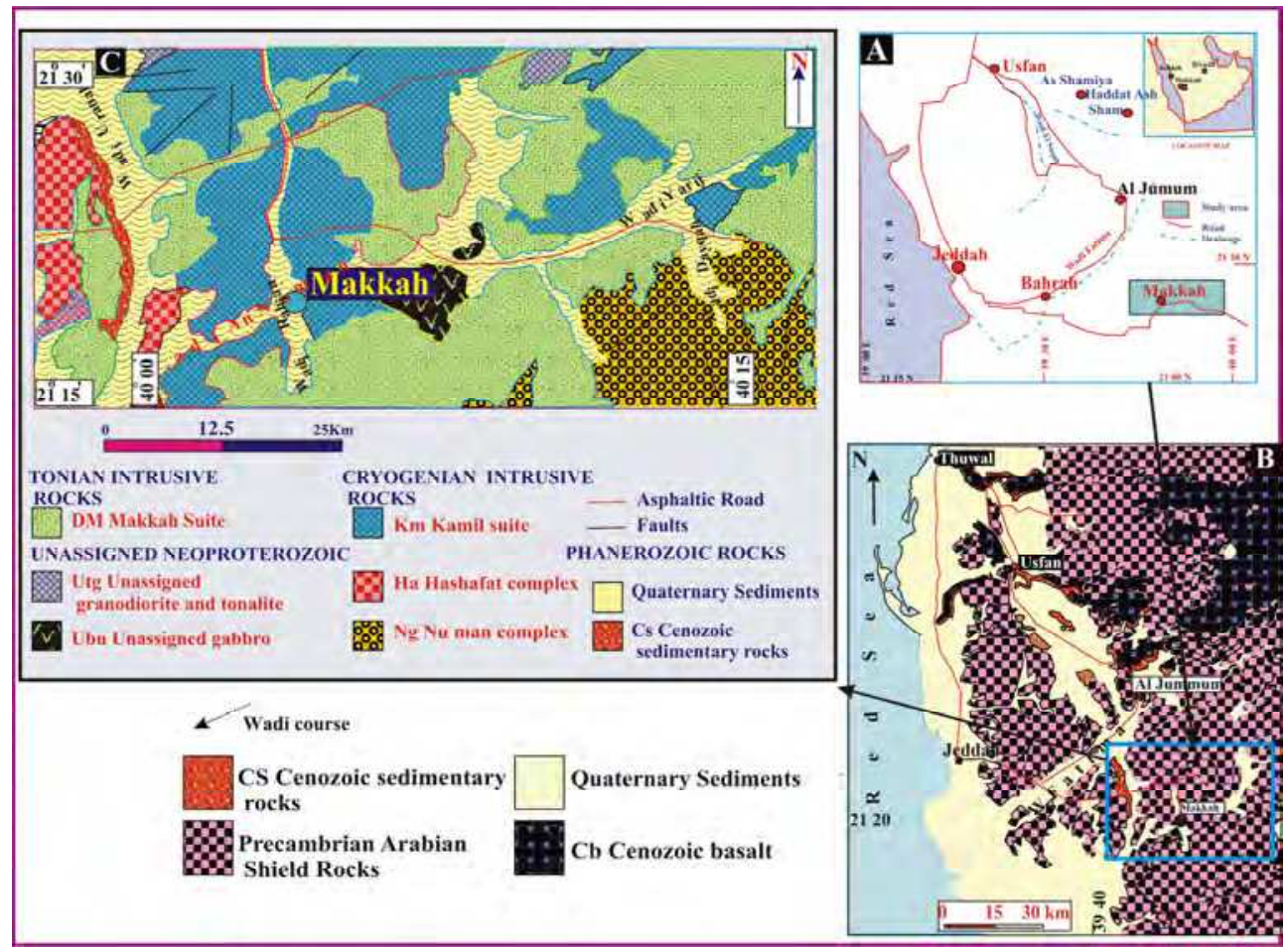

Fig. 11. Geologic map of the study area (Modified after Johnson, 2006 by Sharaf, 2011a).

\subsection{Water hydrochemistry}

The groundwater aquifer in wadi An Numan basin and related sub-basins is present in the Quaternary wadi fill deposits as well as in the weathered fractured crystalline Precambrian bed rocks. The Quaternary alluvial deposits consist of well rounded pebble to boulder size conglomerate. These deposits are essentially recorded in steep-sided wadis. In these areas, 
the alluvial deposits are thin, while in the downstream parts, they are thick and composed of moderately well sorted gravel and medium to fine sand. The water depth maps of wadi An Numan shows that, the wells in the uppermost (recharge areas) tributaries are nearly shallow while the wells within the main channel of wadi An Numan are deeper. The lowest water depth is $25 \mathrm{~m}$ while the highest water depth within the downstream of the main channel of wadi An Numan is about $39 \mathrm{~m}$.

\subsubsection{Sampling and analytical methods}

A total of 65 groundwater samples were collected from the privately owned drilled wells within Wadi An Numan basin. During the field survey and sample collection, groundwater temperature, electrical conductivity (EC) and $\mathrm{pH}$ were measured at the well sites. Most of the groundwater samples were taken from intensively pumped wells in order to avoid any local contamination or change in chemistry caused by evaporation or gas exchange in the well itself. These water samples were analyzed by using Inductively Coupled Plasma-Mass Spectrometry (ICP-MS) in the laboratories of the Faculty of Earth Sciences, King Abdulaziz University, Jeddah, Saudi Arabia. The chemical analyses were performed for the cations $\mathrm{Na}^{+}, \mathrm{K}^{+}, \mathrm{Ca}^{2+}, \mathrm{Mg}^{2+}$ and the anions $\mathrm{HCO}_{3}{ }^{-}, \mathrm{CO}_{3}{ }^{2-}, \mathrm{SO}_{4}^{2-}, \mathrm{Cl}^{-}, \mathrm{NO}_{3}^{-}$.

In Wadi An Numan, the groundwater salinity is rather low with EC ranged from 542 to 5400 $\mu \mathrm{S} / \mathrm{cm}$ with an average of about $1539 \mu \mathrm{S} / \mathrm{cm}$ (Table 3). The dominant water types are $\mathrm{NaCl}$ and $\mathrm{CaCl}_{2}$. The rare and trace elements of the groundwater samples were determined. These are $\mathrm{As}, \mathrm{Mo}, \mathrm{Zn}, \mathrm{P}, \mathrm{Pb}, \mathrm{Co}, \mathrm{Cd}, \mathrm{Ni}, \mathrm{Ba}, \mathrm{Fe}, \mathrm{B}, \mathrm{Si}, \mathrm{Hg}, \mathrm{Mn}, \mathrm{Cr}, \mathrm{V}, \mathrm{Bi}, \mathrm{Cu}, \mathrm{U}, \mathrm{Al}, \mathrm{Li}, \mathrm{Rb}, \mathrm{Au}, \mathrm{Cr}$, $\mathrm{Sr}, \mathrm{F}$ and NH4. The chemical analyses show that, the groundwater is enriched with nitrate $\left(\mathrm{NO}_{3}\right)$ ions and most of the groundwater is very hard for use as a drinking water supply. In addition, a few trace elements showed an increase in their contents and exceed the maximum acceptable limits of the standards that restricted to its utilization for drinking water.

\subsubsection{Description of the groundwater chemistry}

\subsubsection{Durov diagram}

The main purpose of the Durov diagram is to show clustering of data points to indicate samples that have similar compositions (Hem, 1989). The durov diagram of the chemical analyses of the water samples of the different areas (Fig. 12) revealed that, the water types of wadi Dayqah sub-basin are mainly of $\mathrm{CaCl}_{2}$ types except some analyses which are of calcium bicarbonate types. Analyses no. 5, 7, 9, 10 are of calcium sulphate types. The chemical analyses of the main channel of wadi An Numan sub-basin are of calcium chloride and calcium sulphate types with less frequent calcium bicarbonate types. Some analyses are of $\mathrm{NaCl}$ and others are of sodium sulphate water type. In wadi Arar sub-basin the water types are mainly calcium chloride, calcium sulphate and calcium bicarbonate. In wadi Rahjan sub-basin the water types are of calcium chloride and calcium sulphate with less frequent $\mathrm{Na}$ and $\mathrm{Ca}$ bicarbonates and Ca sulphates. From the Durov diagram we notice that, the analyses of the main channel of wadi An Numan are enriched in $\mathrm{Cl}$ and $\mathrm{SO}_{4}$.

\subsubsection{Trilinear diagram}

The plotting of the analyses of the different sub-basins on the trilinear diagram (Fig. 13) revealed that, the groundwater within the study area is predominantly a mixture of 


\begin{tabular}{|c|c|c|c|c|}
\hline Item & Minimum & Maximum & Average & St. Dev. \\
\hline $\mathrm{Ca}$ & 66 & 432 & 154.766 & 72.155 \\
\hline $\mathrm{Mg}$ & 3.26 & 160 & 36.893 & 27.756 \\
\hline $\mathrm{Na}$ & 37.2 & 500 & 101.466 & 77.288 \\
\hline $\mathrm{K}$ & 2.57 & 14.5 & 6.753 & 1.735 \\
\hline $\mathrm{HCO}_{3}$ & 127.9 & 392.5 & 214.36 & 54.221 \\
\hline $\mathrm{SO}_{4}$ & 89.0 & 1350 & 262.252 & 205.664 \\
\hline $\mathrm{SO}_{3}$ & 74.2 & 1125 & 219.007 & 171.415 \\
\hline $\mathrm{NO}_{3}$ & 6 & 560 & 78.32 & 83.5 \\
\hline $\mathrm{Cl}$ & 44 & 1085.8 & 205.075 & 173.17 \\
\hline Sum Cations & 5.943 & 55.894 & 15.344 & 8.814 \\
\hline Sum Anions & 5.579 & 55.945 & 14.758 & 9.099 \\
\hline Alkalinity & 11.74 & 36.028 & 19.676 & 4.977 \\
\hline
\end{tabular}

Table 3. Statistics of the chemical analyses (65 samples, concentrations in $\mathrm{mg} / \mathrm{l}$ ) (Sharaf, 2011a).

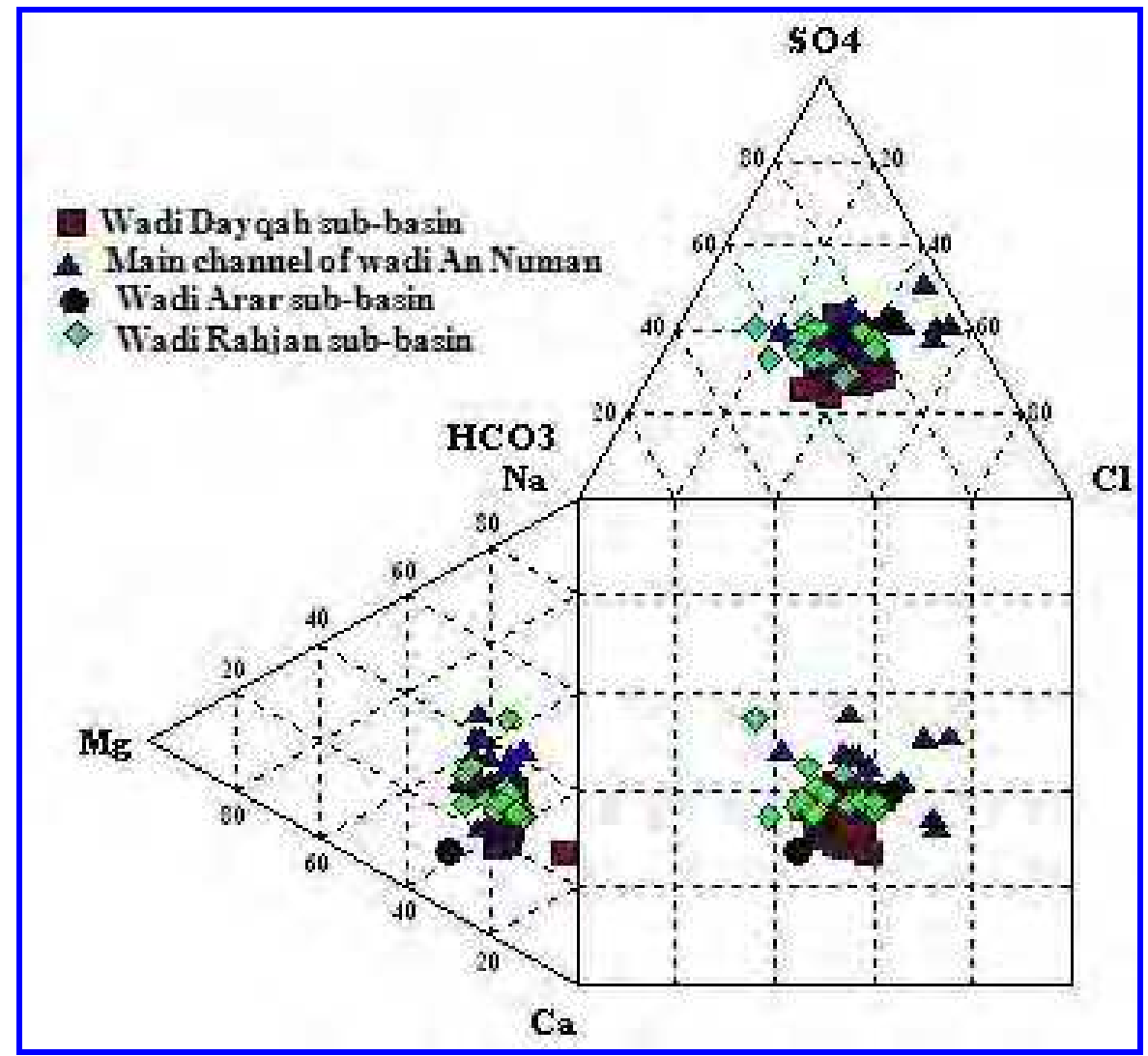

Fig. 12. Durov Diagram of the chemical analyses of the water samples of the different subbasins of wadi An Numan (Sharaf, 2011a). 
calcium-sodium ions and the upper tributaries of Wadi Numan contains fresh water while downstream (main channel of wadi An Numan, Wadi Rahjan and wadi Arar) waters are brackish. This is due to the very slow interaction between the fractured crystalline rocks and the rainfall waters in the upstream (fresh water) while in the downstream, the water is interacted with the alluvial sediments as well as the highly weathered and fractured bed rocks which lead to the addition of $\mathrm{CO}_{3}, \mathrm{Na}, \mathrm{Ca}, \mathrm{K}$ and $\mathrm{Mg}$ to the water with time leading to the formation of saline and brakish waters of $\mathrm{HCO}_{3}^{-}-\mathrm{Ca}_{2}{ }^{+}-\mathrm{Na}^{+}-\mathrm{SO}_{4}{ }^{2-}-\mathrm{Cl}-\mathrm{Ca}_{2}+$ type.

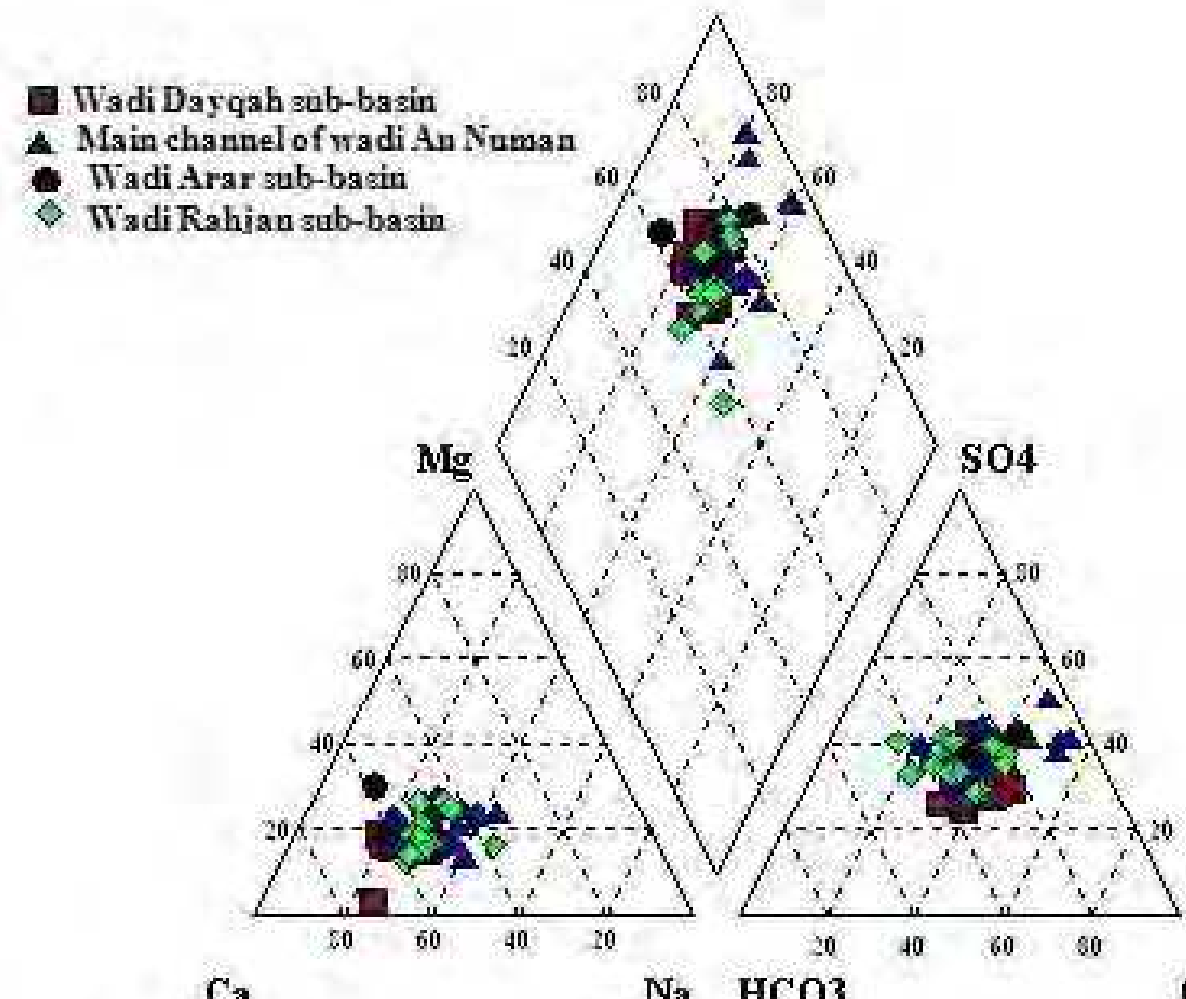

$\mathrm{Ca}$

$\mathrm{Na} \mathrm{HCO} 3$

Fig. 13. Trilinear diagram of the chemical analyses of the ground water samples of the different sub-basins of wadi An Numan (Sharaf, 2011a).

\subsection{Suitability of groundwater}

\subsubsection{Irrigation water}

There are many factors that determine whether groundwater is suitable for irrigation use, which include: 1) the total salt concentration of the water, 2) the concentration of certain ions that may be toxic to plants or that have an unfavorable effect on crop quality; and 3) the concentration of cations such as $\mathrm{Na}^{+}, \mathrm{Ca}^{2+}$ and $\mathrm{Mg}^{2+}$ that can cause deflocculation of the clay in the soil and resulting damage to soil structure and declines in infiltration rate. The 
quality requirements of irrigation water or universal standards for it cannot be formulated, and what might be a poor water at one place could be quite acceptable somewhere else.

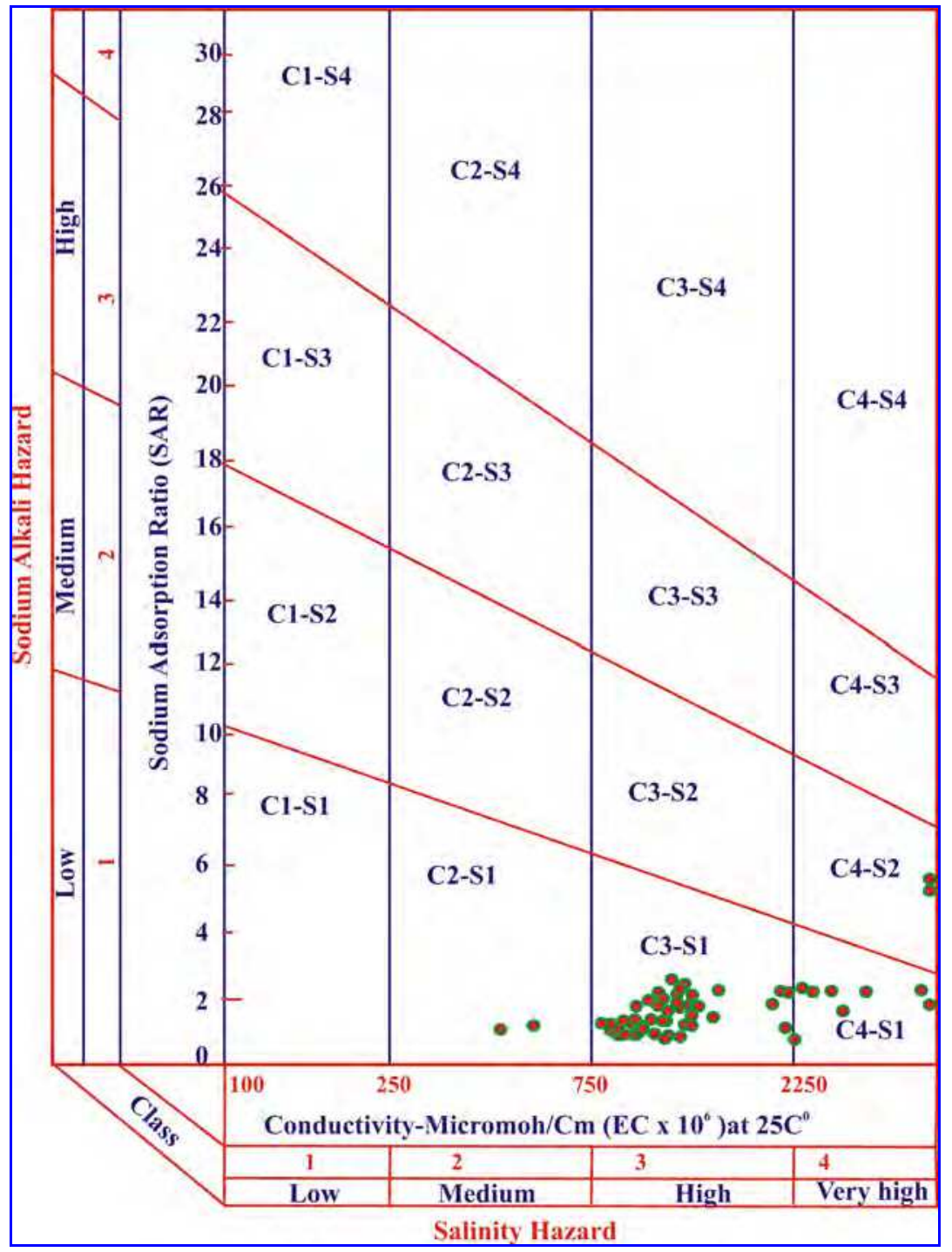

Fig. 14. US Salinity classification of wadi An Numan groundwater for irrigation (USLL, 1954) (Sharaf, 2011a).

Most of the groundwater in Wadi An Numan are fallen within the satisfactory limits. The calculated values of SAR for the groundwater in Wadi An Numan are low according to the recommended water classification for SAR (Lloyd and Heathcote, 1985). The minimum SAR values of wadi An Numan groundwater is 0.8 while the maximum is 5.28 and the average is 
1.85. Wadi An Numan groundwater samples are of SAR values between values 1 and 3 and EC values between 1000 and 3000 (Fig. 14). Most of the samples are located within the C3-S1 and C4-S1. Less frequent samples are present in the fields C2-S1 and C4-S2.

The RSC values for the different sub-basins of wadi An Numan are negative $(<1.25)$. This is because $\mathrm{HCO}_{3}$ - is not an important anion compared to $\mathrm{Cl}$ - and $\mathrm{SO}_{4}{ }^{2-}$ in the groundwater. However, the RSC values in the range found can be used safely for irrigation purposes (Lloyd and Heathcote, 1985). The magnesium hazard (MH) values are $>50$ which are considered to be harmful. In Wadi An Numan, all the groundwater samples are fall within accepted limits which in turn the water can be used safely. Boron is essential for growth of plants in very small concentrations, and becomes of toxic effect when present above the optimum level. Boron in Wadi An Numan groundwater is fallen with satisfactory limits.

Although evaporation probably has the greatest influence on the total dissolved solids (TDS) in the investigated regions, the actual chemical composition is also influenced by other factors. These include the net addition of the major constituents such as $\mathrm{Ca}^{2+}, \mathrm{Mg}^{2+}, \mathrm{K}$, $\mathrm{HCO}_{3}$ and trace elements by weathering of silicate minerals. The Precambrian and intrusive rocks commonly contain the major rock-forming minerals such as hornblende and biotite that enrich in $\mathrm{Ca}^{2+}, \mathrm{Mg}^{2+}, \mathrm{K}^{+}$and Fe. $\mathrm{Na}^{+}$is added by this means but not that much of these ions. Oxidation and dissolution rocks of gabbroic composition will contribute trace elements such as $\mathrm{Ni}, \mathrm{Co}, \mathrm{Cu}, \mathrm{Zn}, \mathrm{Cr}, \mathrm{Li}, \mathrm{Cd}, \mathrm{V}$ and $\mathrm{Mn}$. The source of these trace elements will be associated with the major cations such as $\mathrm{Ca}^{2+}, \mathrm{Mg}^{2+}, \mathrm{Fe}, \mathrm{Na}^{+}, \mathrm{Al}$ and $\mathrm{Si}$ which are considered the major cations in the rocks of gabbroic composition. Whereas, in the weathering granitic rocks will contribute trace elements of $\mathrm{Cu}, \mathrm{Ba}, \mathrm{Rb}, \mathrm{Pb}, \mathrm{As}, \mathrm{Mo}, \mathrm{U}$ and $\mathrm{Br}$. These elements will be associated with the major ions such as $\mathrm{Na}^{+}, \mathrm{K}^{+}, \mathrm{Al}$ and $\mathrm{Si}$. However, the released trace elements almost occur as lattice substitutes impurities or in solid solution.

Evaporation, recycling of irrigation water and chemical weathering reactions of silicate minerals are the dominate processes affecting the groundwater's chemical composition. The first two processes possibly worked collectively and lead to precipitate evaporitic salts in the irrigated fields around the production wells. Calcite, dolomite and gypsum are the dominant evaporitic salts. The groundwater in the study area seems to be suitable when compared with FAO quality criteria for irrigation. The calculated values of SAR, RSC, and Magnesium hazard indicate well to permissible use of ground water for this aim.

\section{Wadi Fatimah}

Wadi Fatimah is shallow alluvial and fracture bedrock aquifer in western part of Saudi Arabia, and considered as one of the major source of water supplies in the area. Because of the rapid growth of population, long time of aridity and intensive exploitation of groundwater resources from this wadi has led to concern about potential water quality impacts. Alyamani (2007) studied the nitrate concentration in the upper reaches of Wadi Fatimah. His study shows that the nitrate concentration in the groundwater exceeded the maximum contaminant level due to the effects of cesspool system in the upper reach of the basin.

Wadi Fatimah basin comprises the most important drainage system in the western province of Saudi Arabia (Fig. 5). It considered the major important sources of groundwater to the cities of Makkah, Jeddah and the surrounding villages and towns. The Red Sea escarpment 
(Hijaz Highlands) and Harrat Rahat are considered the recharge areas of these basins. Generally, the main course of the basin follow westerly to southwesterly directions towards the Red Sea coast. The drainage of the basins generally is well developed and the pattern is typically dendritic (Fig. 5). Although the local relief generally less than 400 meters above the wadi floor, the wadi networks have many small and large tributaries. They are deep and narrow and their longitudinal profiles are rather gentle and in some areas become irregular. They almost follow N-S, NW-SE and SE-NW directions, which probably controlled by major structures, and smaller faults that commonly control lesser drainage channels. The upper stream parts of the basin is rather narrow, where the width of the main wadi course vary from less than $100 \mathrm{~m}$ to more than $1.5 \mathrm{~km}$ further downstream, where the alluvium deposits are widespread and rather thicker.

Groundwater samples of the main stream were taken from the alluvial and fracture aquifer in winter, 2004. Trace elements were analyzed in each sample for a total of 17 water quality descriptors (variables), these elements are: $\mathrm{As}, \mathrm{Zn}, \mathrm{P}, \mathrm{Pb}, \mathrm{Ba}, \mathrm{B}, \mathrm{Si}, \mathrm{Al}, \mathrm{Li}, \mathrm{Cu}, \mathrm{Fe}, \mathrm{Hg}, \mathrm{Mn}$, $\mathrm{Cd}, \mathrm{V}$, and $\mathrm{Rb}$. Among these, only $\mathrm{pH}$ was measured in the field. Samples were analyzed in the laboratories of the Faculty of Earth Sciences, Saudi Arabia. The accuracy of this analytical technique was controlled using appropriate standards. Statistical summary including the mean, standard deviation, coefficient of variation, and skewness of trace elements are shown in Table 4.

The analysed trace elements of wadi Fatimah (Table 4) show the following distribution: In the study area, according to Sharaf and Subyani (2011) the average Al content is $0.062 \mathrm{mg} / 1$ which is very low when compared with $\mathrm{WHO}$ guideline of $\mathrm{Al}(0.2 \mathrm{mg} / \mathrm{l})$. The concentration of $\mathrm{Al}$ will depend on the availability and extent of weathering of the aluminosilicates such as clays, pyrophyllites, feldspars, micas and other related minerals. High concentration of $\mathrm{Al}$ in soils and groundwater may also be attributed to a number of factors including the availability of dissolved organic matter and fluoride (Edmunds et al., 1992). Arsenic (As): which is the most important element affecting the groundwater quality. The average value of arsenic is $0.015 \mathrm{mg} / \mathrm{l}$ which similar to that recommended by the WHO. The average barium content of wadi Fatimah area is $0.208 \mathrm{mg} / 1$ which is similar to the WHO $(0.3 \mathrm{mg} / \mathrm{l})$. The maximum value of boron is $8.54 \mathrm{mg} / 1$ while its minimum value is 0.372 and the average is $1.6126 \mathrm{mg} / \mathrm{l}$ which is higher than that recorded in the normal groundwater and also higher than the WHO (1993) recommended values $(0.3 \mathrm{mg} / \mathrm{l})$. The toxic effect for B in humans is found to occur above $20 \mathrm{mg} / 1-1$ (Bolt and Bruggenwert, 1978). Boron usually occurs as a nonionized form as $\mathrm{H} 3 \mathrm{BO}$ in soils at $\mathrm{pH}$ less than 8.5, but above this $\mathrm{pH}$, it exists as an anion, $\mathrm{B}(\mathrm{OH}) 4-1$. It is very soluble in soils and can be leached especially in sandy soils (Brady, 1974). It is also dispersed in the environment through fertilizer application. Since the $\mathrm{pH}$ was less than 8.5 for all the samples, it is more likely that $\mathrm{B}$ would be in the non ionized than the ionized state.

The cadmium in wadi Fatimah groundwater is higher than that recommended by the WHO guideline. The average of $\mathrm{Cd}$ is $0.004 \mathrm{mg} / \mathrm{l}$. Cadmium is used normally as a coating material, paint pigment, in plastics, fungicide and is a constituent of some fertilizers. Copper, $\mathrm{Cd}$ and $\mathrm{Zn}$ exist in aqueous form in the predominately ${ }^{+} 2$ state. Generally, $\mathrm{Zn}$ exists as $\mathrm{Zn}^{2+}$ state in $\mathrm{pH}$ below 7.7 (Liptrot, 1989). Cadmium (II) oxide occurs in some Zn ores which suggests that the two have identical properties such as that both have the +2 being the most stable oxidation state (Liptrot, 1989). In natural waters, $\mathrm{Cu}, \mathrm{Cd}$ and $\mathrm{Zn}$ occur in the ${ }^{+2}$ 


\begin{tabular}{|c|c|c|c|c|c|c|}
\hline & Max & Min & Mean & St.Dev. & Skew & Co.Var. \\
\hline $\mathbf{A s}$ & 0.09 & 0.00026 & 0.015 & 0.023 & 1.98 & 1.55 \\
\hline $\mathbf{Z n}$ & 0.36 & 0.0001 & 0.044 & 0.069 & 3.32 & 1.59 \\
\hline $\mathbf{P}$ & 4.16 & 0.046 & 0.626 & 0.540 & 3.35 & 0.86 \\
\hline $\mathbf{P b}$ & 0.07 & 0.001 & 0.020 & 0.020 & 1.41 & 1.00 \\
\hline $\mathbf{B a}$ & 0.56 & 0.037 & 0.208 & 0.088 & 0.64 & 0.42 \\
\hline $\mathbf{B}$ & 8.54 & 0.372 & 1.612 & 1.390 & 2.45 & 0.86 \\
\hline $\mathbf{S i}$ & 25.06 & 4.89 & 9.832 & 3.004 & 2.07 & 0.31 \\
\hline $\mathbf{A l}$ & 0.90 & 0.00256 & 0.062 & 0.152 & 3.25 & 2.46 \\
\hline $\mathbf{L i}$ & 0.60 & 0.002 & 0.089 & 0.145 & 2.35 & 1.62 \\
\hline $\mathbf{C u}$ & 0.06 & 0.0013 & 0.021 & 0.012 & 0.64 & 0.58 \\
\hline $\mathbf{F e}$ & 0.32 & 0.005 & 0.032 & 0.054 & 4.42 & 1.68 \\
\hline $\mathbf{H g}$ & 0.17 & 0 & 0.018 & 0.038 & 3.05 & 2.10 \\
\hline $\mathbf{M n}$ & 0.28 & 0.001 & 0.020 & 0.037 & 5.10 & 1.84 \\
\hline $\mathbf{C d}$ & 0.02 & 0.0001 & 0.004 & 0.004 & 1.71 & 1.06 \\
\hline $\mathbf{V}$ & 0.70 & 0.00213 & 0.213 & 0.196 & 0.19 & 0.92 \\
\hline $\mathbf{R b}$ & 0.16 & 0.0046 & 0.097 & 0.055 & -0.42 & 0.57 \\
\hline $\mathbf{P h}$ & 7.90 & 7.1 & 7.487 & 0.205 & 0.36 & 0.03 \\
\hline
\end{tabular}

Table 4. Statistical summary for trace elements (mg/1) (Sharfa \& Subyani, 2011e).

form. The average cupper content of wadi Fatimah is $0.021 \mathrm{mg} / 1$ which is very low when compared with that of WHO (2 mg/l). The average Fe content is $0.032 \mathrm{mg} / 1$ which is lower than the recommended WHO iron level $(<0.3 \mathrm{mg} / \mathrm{l})$. Iron dissolved in groundwater is in the reduced ferrous iron form. This form is soluble and normally does not cause any problems by itself. Ferrous iron is oxidized into ferric iron on contact with oxygen in the air or by the action of iron related bacteria. Ferric iron forms insoluble hydroxides in water. These are rusty red and cause staining and blockage of screens, pumps, pipes, reticulation systems etc. If the iron hydroxide deposits are produced by iron bacteria then they are also sticky and the problems of stain and blockage are many times worse. 
Lead (average $0.001 \mathrm{mg} / \mathrm{l}$ ) and it is relatively higher than the WHO (0.01). Lead on the other hand is used in automobile industries in form of tetramethyllead and tetraethyllead. Manganese $(\mathrm{Mn})$ is present in wadi Fatimah by very low content (average $0.020 \mathrm{mg} / \mathrm{l}$ ) and it is relatively lower than the WHO $(0.01)$. Mercury $(\mathrm{Hg})$ is important for the water quality. The average $\mathrm{Hg}$ in wadi Fatimah area is $0.018 \mathrm{mg} / 1$ (Table 3) which is relatively higher than the WHO values.

Oxidation and dissolution rocks of gabbroic composition will contribute trace elements such as, $\mathrm{Cu}, \mathrm{Zn}, \mathrm{Li}, \mathrm{Cd}, \mathrm{V}$ and $\mathrm{Mn}$. The source of these trace elements will be associated with the major cations such as $\mathrm{Ca}^{2+}, \mathrm{Mg}^{2+}, \mathrm{Fe}, \mathrm{Na}+, \mathrm{Al}$ and $\mathrm{Si}$ which are considered the major cations in the rocks of gabbroic composition. Whereas, in the weathering granitic rocks will contribute trace elements of $\mathrm{Cu}, \mathrm{Ba}, \mathrm{Rb}, \mathrm{Pb}$ and $\mathrm{As}$, These elements will be associated with the major ions such as $\mathrm{Na}+, \mathrm{K}+, \mathrm{Al}$ and $\mathrm{Si}$.

In Wadi Fatimah the groundwater salinity ranged between 969 to $26.500 \mu \mathrm{S} / \mathrm{cm}$. All the subbasins are characterized by a relatively low to medium saline water. Highly mineralized water zone almost found marked the lower part of the wadi e.g. Al Jumum-Bahrah area, where the groundwater salinity reached up to $26.500 \mu \mathrm{S} / \mathrm{cm}$ with an average of about 9500 $\mu \mathrm{S} / \mathrm{cm}$.

Based on the irrigation indices (e.g. EC, SAR, RSC, B, MH and chloride hazard), it can be concluded that the groundwater within with exception of those located in the Al JumumBahrah region in Wadi Fatimah basin, although its salinity ranged from medium to high, the groundwater can be safely used for irrigation.

For domestic purposes, the groundwater can be used safely in Fatimah basins. Within Wadi Fatimah, the analyses showed most of the groundwater to be too mineralized and very hard for use as a drinking water supply. In addition, a few trace elements showed increases in their contents and exceed the maximum acceptable limits which restricted to its utilization for drinking water, such as As, B and Mo.

\section{Conclusions}

The results of this study revealed that most of the water resources in Jeddah-Makkah area are present within the underground aquifers. These aquifers are of two main types: 1) shallow aquifers within the Quaternary alluvial deposits, and 2) The Oligo-Miocene siliciclastic succession of Ash Shumaysi and Haddat Ash Sham formations. In wadi Usfan, The results of theexploration tools revealed the following conclusions: a)The shallow zone is characterized with a saturated thickness of 3- $20 \mathrm{~m}$ and water is found under confined to semi-confined conditions, b) Water levels were encountered at depths varying from 3-16m in the alluvial wadi deposits, and from 18-62 $\mathrm{m}$ in the sedimentary succession, c) Groundwater movement is towards the west and northwest, following the general surface drainage system, and d) Hydraulic gradient varies greatly from one point to another depending on the pumping rates and cross-sectional area of the aquifer in addition to its transmissivity.

In wadi An numan area, the groundwater salinity is rather low with EC ranged from 542 to $5400 \mu \mathrm{S} / \mathrm{cm}$ with an average of about $1539 \mu \mathrm{S} / \mathrm{cm}$. The dominant water types are $\mathrm{NaCl}$ 
and $\mathrm{CaCl}_{2}$. The chemical analyses show that, the groundwater is enriched with nitrate $\left(\mathrm{NO}_{3}\right)$ ions and most of the groundwater is very hard for use as a drinking water supply. In addition, a few trace elements showed an increase in their contents and exceed the maximum acceptable limits of the standards that restricted to its utilization for drinking water.

In Wadi Fatimah the groundwater salinity ranged between 969 to $26.500 \mu \mathrm{S} / \mathrm{cm}$. Highly mineralized water zone almost found marked the lower part of the wadi e.g. Al Jumum-Bahrah area, where the groundwater salinity reached up to $26.500 \mu \mathrm{S} / \mathrm{cm}$ with an average of about $9500 \mu \mathrm{S} / \mathrm{cm}$. Based on the irrigation indices (e.g. EC, SAR, RSC, B, $\mathrm{MH}$ and chloride hazard), it can be concluded that the groundwater within with exception of those located in the Al Jumum-Bahrah region in Wadi Fatimah basin, although its salinity ranged from medium to high, the groundwater can be safely used for irrigation.

\section{Acknowledgment}

The author would like to thank the staff members of the geophysical team of the project NO. AT, 16-20 funded by the King Abdulaziz City for Science and Technology (KACST). He also introduce deep thanks for the Deanship of Scientific Research and post graduate studies of King Abdulaziz University (KAU), Saudi Arabia.

\section{References}

Al Kabir, M. A.(1985) Recharge characteristics of groundwater aquifers in Jeddah-MakkahTaif area. M.Sc. Thesis, Faculty of Earth Sci., King Abdulaziz Uni., Jeddah, Saudi Arabia.

Alawi, J. and Abdulrazzak, M. 1993. Water in the Arabian Peninsula: Problems and Prospective. In P. Rogers, and P. Lydon (eds), Water in the Arab World Perspectives and Prognoses:171-202. Division of Applied Sciences: Harvard University.

Al-Gamal,S.A., and Sen,Z.(1983) Quantitative analysis of groundwater quality in Western Saudi Arabia. Proc. Int. Symp. Noordwijkuhout.

Al-Hageri, F.Y., 1977. Groundwater studies of Wadi Qudaid. Institute of applied geology, King Abdulaziz University, Jeddah, Saudi Arabia. Research series no. 2. 132178.

Al-Khatib,E.A.B.(1977) Hydrogeology of Usfan District. M.Sc. Thesis, Institute of Applied Geology, King Abdulaziz Uni., Jeddah, Saudi Arabia.

Al-Nujaidi,H,A.(1978) Hydrogeology of Wade Murawani- Khulais. M.Sc.Thesis, Institute of Applied Geology, King Abdulaziz Uni., Jeddah, Saudi Arabia.

Alyaamani, MS., and Hussein,M.T.(1995) Hydrochemical study of groundwater in recharge area, Wade Fatimah basin, Saudi Arabia. Geo Journal, 37.1, p:81-89.

Alyamani, M. (2007) Effects of cesspool system on groundwater quality of shallow bedrock aquifers in the recharge area of Wadi Fatimah, Western Arabian Shield, Saudi Arabia. J. Env. Hydrology, vol. 15, paper 8. 
Alyamani, M.S.(1999). Physio-chemical processes on groundwater chemistry, under arid climatic conditions,western province, Saudi Arabia. Proj. No. 203/418, King Abdulaziz Uni., Jeddah, Saudi Arabia.

Alyamani, M.S., Bazuhair, A. S., Bayumi, T. H., and Al-Sulaiman, K. (1996) Application of environmental isotope on groundwater study in the western province, Saudi Arabia. Proj. No. 005/413, King Abdulaziz Uni., Jeddah, Saudi Arabia.

Basmci, Y., and Al Kabir, M.A. (1988). Recharge characteristics of aquifers of JeddahMakkah-Taif region. Mathematical and Physical Sci., Vol. 222, p: 367-375.

Bazuhair, A.S., Hussein,M.T., Alyamani,M.S., and Ibrahim, K.(1992) Hydrogeophysical studies of Khulais basin, western region, Saudi Arabia. Unpub. Report, King Abdulaziz Uni, Jeddah, Saudi Arabia.

Bolt, G. H. and Bruggenwert, M. G. M.: 1978, Soil Chemistry, Basic Elements, 2nd Edition, Elsevier Scientific Publishing Company Amsterdam. The Netherlands.

Brady, N. C.: 1974, Nature and properties of soils, 8th EditionMacmillan Publishers Co., INC, NewYork Brady, N. C.: 1974, Nature and properties of soils, 8th EditionMacmillan Publishers Co., INC, NewYork.

Brown, G.F., Jackson, R.O., Bogue, R.G., and MacLean, W.H. (1963) Geology of the Southern Hijaz quadrangle, Kingdom of Saudi Arabia: Saudi Arabian Dir. Gen. Min. Res.Misc. Geologic Invest. Map I - 210A, 1:500,000 scale.

Burden, D.J. 1982. Hydrogeological conditions in the Middle East. Quarterly Journal of Engineering Geology 15: 71-81.

Edmunds. W. M., Kinniburgh, D. G. and Moss, P. D.: 1992, Trace Metals in Interstitial Waters from Sandstones Acidic Inputs to Shallow Groundwater, Environmental Pollution, Elsevier Science Publishers Ltd, England. Edmunds, W. M. and Savage, D.: Geochemical Characteristics of Groundwater in Granites and Related Crystalline Rocks. (Unpublished).

Hem, 1989 Hem, J.D. (1989) The Study and Interpretation of the Chemical Characteristics of Natural Water. 3rd edn. USGS Water Supply Paper 2254, US Geological Survey.

Italconsult (1976) Detailed investigations of Wade Khulais basin. Unpub. Report. Ministry of Agriculture and Water, Riyadh, Saudi Arabia

Jamman, A. M. (1978) Hydrogeology of Wadi An Numan, Saudi Arabia. Unpub M. Sc.Thesis, Faculty of Earth Sci., King Abdulaziz Uni., Jeddah, Saudi Arabia. M.Sc. Thesis, Institute of Applied Geology, King Abdulaziz Uni., Jeddah, Saudi Arabia.

Johnson, P. R. (2006) Explanatory notes to the map of Proterozoic geology of western Saudi Arabia, technical report SGS-Tr-2006-4.

Karpoff, R.,1958. Esquisse geologiques de I,Arabie Saoudite : Bulletin Societe Geologique de France, 6 ser. VIIm, pp. $653-696$.

Kfupm/Ri (King Fahd University of Petroleum and Minerals, Research Institute) 1988. Groundwater Resources Conditions in the Eastern Province of Saudi Arabia, Research report, King Fahd University of Petroleum and Minerals, Research Institute. $61 \mathrm{pp}$

Liptrot, G. F.: 1989, Modern Inorganic Chemistry 4th Edit, Scoltprint Musselburgh. 
Lloyd and Heathcote, 1985 Lloyd, J. A., and Heathcote, J.A. (1985) Natural inorganic hydrochemistry in relation to groundwater: An introduction. Oxford Uni. Press, New YorK p: 296.

Mansour, M. A. (1984) Evaluation of groundwater resources of Wade Fatimah by Numerical model. Unpub. M.Sc.Thesis, Faculty of Earth Sci., King Abdulaziz Uni., Jeddah, Saudi Arabia.

MAW (Ministry of Agriculture and Water) 1984. Water Atlas of Saudi Arabia. Department of Water Resources Development, Ministry of Agriculture and Water, Riyadh, Saudi Arabia.

Moore, T. A., and Al-Rehaili, M.H. (1989) Explantory notes to the geologic map of the Makkah quadrangle, sheet21D, Kingdom of Saudi Arabia: Saudi Arabian Dir. Gen. Min. Res. Geoscience map GM-107C, 1:250,000 scale.

Sharaf, M. A. M. (2010a): Geophysical and Hydrochemical Studies on the Groundwater Aquifer in Ash Shamiyah Area, Makkah District, Western Saudi Arabia. Journal of Environmental Hydrology, Paper 13, V. 18, 2010).

Sharaf, M. A. M. (2010b): Hydrogeology of Haddat Ash Sham area: Geophysical and hydrochemical Constrains. Fifth 5th International Conference on the Geology of the Tethys Realm, South Valley University, January 2010, P.147-158.

Sharaf, M. A. M. (2011a): Hydrogeological and hydrochemistry of the aquifer system of Wadi An Numan, Makkah Al Mukarramah, Saudi Arabia. AquaMundi: Journal of Water Science, (2011)-Am03027: 035 - 052

Sharaf, M. A. M. (2011b): Geological and Geophysical Exploration of the Groundwater Aquifers of As Suqah Area, Makkah District, Western Arabian Shield. Arab J Geosci (2011) 4:993-1004.

Sharaf, M. A. M. (2011c): Hydrochemistry of the Groundwater Aquifer in wadi FaydahUsfan Areas, Makkah District, Western Arabian Shield, Saudi Arabia. Egyptian Journal of Geology, v. 55, 2011, p.1-13.

Sharaf, M. A. M. (2011d): Hydrochemistry of the Groundwater Aquifer in As Suqah Area, Makkah District, Western Arabian Shield, Saudi Arabia. (In Press in the Journal of King Abdulaziz University (Earth Sciences) JKAU, V. 22, 2011).

Sharaf, M.A.M and Subyani, A. M. (2011e): Assessing of Groundwater Contamination by Toxic Elements through Multivariate Statistics and Spatial Interpolation, Wadi Fatimah, Western Arabian Shield, Saudi Arabia. International Journal of Scientific \& Engineering Research Volume 2, Issue 9, September-2011.

Sharaf, M. A., Farag, M. H., and Gazzaz, M. (1988) Groundwater chemistry of WadiUoranah- Alabdiah area. Western Province, Saudi Arabia, JKAU: Earth Sci. 1, 103-112.

Sharaf, M.A., Al-Bassam,A., Bayumi, T.H., and Qari,M. H. (2002) Hydrogeological and hydrochemical investigation of the Cretaceous- Quaternary sedimentary sequence east of Jeddah city. King Abdulaziz City for Science and Technology (KACST), Final Report, Riyadh, Saudi Arabia.

Spincer, C. H.,and Vincent, P. L., 1984, Bentonite resource potential and geology of the Cenozoic sediments, Jeddah region: Saudi Arabian Deputy Ministry for Mineral Resources, Open-File Report BRGM-O-F-02-34, 34 p. 
USSL 1954: Diagnosis and improvement of saline and alkali soils. USDA Agr. Handbook No. 60, Washington DC WHO (1993) Guidelines for Drinking Water Quality, Geneva

Zaidi, S. (1983) Landform and geomorphic evolution of Wade Khulais area.Western Saudi Arabia. FES, Bull. 5, 153-156pp.

Zaidi, S.(1984) Geomorphology of Wadi Khulais area. FES, Res. Ser. No.18, 98p. 


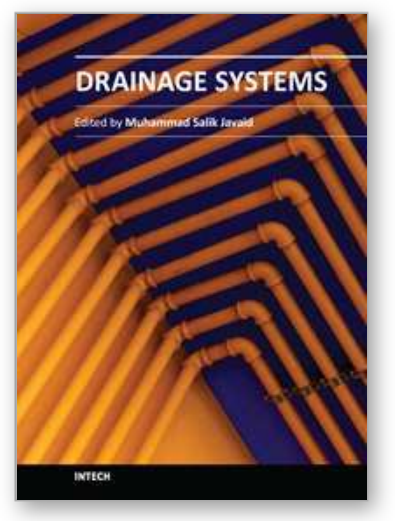

\author{
Drainage Systems \\ Edited by Prof. Muhammad Salik Javaid
}

ISBN 978-953-51-0243-4

Hard cover, 240 pages

Publisher InTech

Published online 07, March, 2012

Published in print edition March, 2012

The subject of 'drainage: draining the water off' is as important as 'irrigation: application of water', if not more. 'Drainage' has a deep impact on food security, agricultural activity, hygiene and sanitation, municipal usage, land reclamation and usage, flood and debris flow control, hydrological disaster management, ecological and environmental balance, and water resource management. 'Drainage Systems' provides the reader with a tridimensional expose of drainage in terms of sustainable systems, surface drainage and subsurface drainage. Ten eminent authors and their colleagues with varied technical backgrounds and experiences from around the world have dealt with extensive range of issues concerning the drainage phenomenon. Field engineers, hydrologists, academics and graduate students will find this book equally benefitting.

\title{
How to reference
}

In order to correctly reference this scholarly work, feel free to copy and paste the following:

Mohammed Amin M. Sharaf (2012). A Study of Subsurface Drainage and Water Quality in Jeddah-Makkah Aquifer Zone, West Central Arabian Shield, Saudi Arabia, Drainage Systems, Prof. Muhammad Salik Javaid (Ed.), ISBN: 978-953-51-0243-4, InTech, Available from: http://www.intechopen.com/books/drainagesystems/ground-water-aquifers-in-jeddah-makkah-al-mukarramah-district-west-central-saudi-arabia-

\section{INTECH}

open science | open minds

\section{InTech Europe}

University Campus STeP Ri Slavka Krautzeka 83/A 51000 Rijeka, Croatia Phone: +385 (51) 770447 Fax: +385 (51) 686166 www.intechopen.com

\section{InTech China}

Unit 405, Office Block, Hotel Equatorial Shanghai No.65, Yan An Road (West), Shanghai, 200040, China 中国上海市延安西路65号上海国际贵都大饭店办公楼405单元 Phone: +86-21-62489820

Fax: +86-21-62489821 
(C) 2012 The Author(s). Licensee IntechOpen. This is an open access article distributed under the terms of the Creative Commons Attribution 3.0 License, which permits unrestricted use, distribution, and reproduction in any medium, provided the original work is properly cited. 